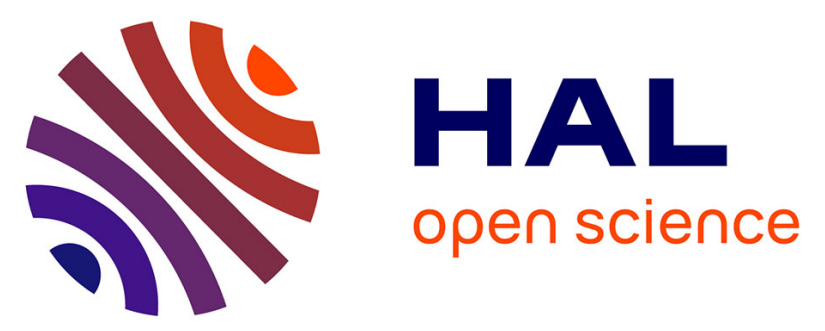

\title{
Scale interaction processes during the MAP IOP 12 south föhn event in the Rhine Valley
}

Philippe Drobinski, Christian Haeberli, Evelyne Richard, Marie Lothon, Alain Dabas, Pierre H. Flamant, Markus Furger, Reinhold Steinacker

\section{- To cite this version:}

Philippe Drobinski, Christian Haeberli, Evelyne Richard, Marie Lothon, Alain Dabas, et al.. Scale interaction processes during the MAP IOP 12 south föhn event in the Rhine Valley. Quarterly Journal of the Royal Meteorological Society, 2003, 129 (588), pp.729-754. 10.1256/qj.02.35 . hal-00137826

\section{HAL Id: hal-00137826 \\ https://hal.science/hal-00137826}

Submitted on 9 Aug 2021

HAL is a multi-disciplinary open access archive for the deposit and dissemination of scientific research documents, whether they are published or not. The documents may come from teaching and research institutions in France or abroad, or from public or private research centers.
L'archive ouverte pluridisciplinaire HAL, est destinée au dépôt et à la diffusion de documents scientifiques de niveau recherche, publiés ou non, émanant des établissements d'enseignement et de recherche français ou étrangers, des laboratoires publics ou privés.

\section{(c)(1)}

Distributed under a Creative Commons Attribution| 4.0 International License 


\title{
Scale interaction processes during the MAP IOP 12 south föhn event in the Rhine Valley
}

\author{
By P. DROBINSKI ${ }^{1,2 *}$, C. HAEBERLI ${ }^{3,4}$, E. RICHARD ${ }^{5}$, M. LOTHON ${ }^{5}$, A. M. DABAS ${ }^{6}$, P. H. FLAMANT ${ }^{2}$, \\ M. FURGER ${ }^{7}$ and R. STEINACKER ${ }^{4}$ \\ ${ }^{1}$ Service d'Aéronomie, Paris, France \\ ${ }^{2}$ Laboratoire de Météorologie Dynamique (LMD), CNRS, Palaisea, France \\ ${ }^{3}$ MeteoSwiss, Zurich, Switzerland \\ ${ }^{4}$ University of Vienna, Austria \\ ${ }^{5}$ Laboratoire d'Aérologie, CNRS and Université Paul Sabatier, Toulouse, France \\ ${ }^{6}$ CNRM, Météo-France, Toulouse, France \\ ${ }^{7}$ Paul Scherrer Institut, Villigen, Switzerland
}

\section{SUMMARY}

This paper examines the three-dimensional structure and dynamics of a south föhn flow in the Rhine Valley during its entire life cycle from 29 October 1999 until 31 October 1999. The south föhn event was documented in the framework of the Mesoscale Alpine Programme (MAP). This study investigates the synoptic-scale forcing sources, the dynamical processes driving the circulation of the föhn flow in the complex network of tributaries of the Rhine Valley, and the degree of inhomogeneity on the scale of the FORM ('FOehn in the Rhine Valley during the MAP' programme) target area at the bifurcation between the Rhine and Seez Valleys. Several important data sources were used (ground-based Doppler lidar, scintillometers, constant-volume balloons, radiosoundings and surface stations) as well as non-hydrostatic mesoscale simulations.

The föhn penetrating the FORM target area on 30 October 1999 is preceded by a nocturnal shallow föhn phase which does not penetrate down to the ground due to katabatic drainage flow from the main transverse (east-west oriented) tributaries in which föhn cannot penetrate. This paper shows the contribution of the main tributaries of the Rhine Valley in directing the föhn flow towards the FORM target area during (i) the shallow föhn phase where the westerly upper-level flow is deflected in the main longitudinal (i.e. north-south oriented) tributaries; (ii) the penetrating föhn phase, where the south/south-westerly upper-level flow is nearly aligned with the longitudinal tributaries. The channelling efficiency of the main longitudinal tributaries of the Rhine Valley (particularly the Domleschg) is higher during the föhn phase when the south-westerly upper-level flow, experiencing mountain-wave-induced downward motion, penetrates these tributaries, than during the shallow föhn.

In the FORM target area, the structure of the föhn flow varies on a 1-kilometre horizontal length-scale and the time evolution of the respective location of the cold air pool and the warm föhn air is investigated in detail. Also, flow splitting between the Rhine and Seez Valleys occurs during the entire föhn life cycle, but its vertical extension is maximum during shallow föhn, when lower- and upper-level flows are fully decoupled.

KEYwords: Katabatic flow Mesoscale Alpine Programme Mountain waves Orographic flow Valley flow

\section{INTRODUCTION}

Föhn is a generic term for strong downslope winds experiencing warming and heating in the lee of a mountain ridge. Föhn is linked with a decrease of cloudiness in the lee and is strong and gusty and often channelled in the numerous gaps and valleys of the ridge (Brinkmann 1971; Seibert 1990). Föhn may cause damage due to severe storms (Brinkmann 1974), snow melting (Hoinka 1985), or high pollution levels (Nkemdirim and Leggat 1978; Hoinka and Rösler 1987) and it is of course of great importance to better understand and predict the structure of the föhn flow.

The favourable synoptic-scale feature leading to south föhn north of the Alps is usually a south/south-westerly basic flow, in general preceding the passage of a cold front in the Alpine region (Hoinka 1980). A distinction is made between shallow föhn, which systematically starts typical föhn episodes (Seibert 1990), and deep föhn. In contrast to the deep föhn, the cross-Alpine southerly flow is essentially confined to the valley transects, whereas the mid-tropospheric flow can have a westerly or even a

\footnotetext{
* Corresponding author: Service d'Aéronomie, Université Pierre et Marie Curie, Tour 15 Couloir 15-14, 4, Place Jussieu, 75252 Paris Cédex 05, France. e-mail: philippe.drobinski@aero.jussieu.f r
} 
north-westerly direction, which can be associated with an approaching cold front which ultimately terminates the föhn storm (Egger 1988; Heimann 1992).

The mesoscale processes that deflect and channel the westerly upper-level flow with the valleys during the shallow föhn phase have been investigated by Sprenger and Schär (2001) and Zängl (2002) and are similar to the counter-current theory (e.g. Wippermann 1984). Sprenger and Schär (2001) also show that during shallow föhn, the complex three-dimensional Alpine ridge can give rise to flow separation and splitting in the vicinity of the valleys and gaps, and these may induce anomalies of potential vorticity and wake features to the lee. During deep föhn, the mechanisms causing the air to descend and displace the colder and denser air in the lee are closely connected to the existence of large-amplitude lee waves and/or hydraulic jump (Brinkmann 1971; Hoinka 1985) which can eventually intensify the föhn flow along the gaps and valleys transecting the ridge (e.g. Zängl 1999; Flamant et al. 2002). The föhn penetrating down to the surface erodes the cold surface layer or cold pool, transported from polar regions and formed when an absence of clouds permits the ground to radiate freely towards space, up to $50 \mathrm{~km}$ north of the baseline (Hoinka and Rösler 1987).

In most of the aforementioned studies, the instrumental set-up did not allow an overall three-dimensional documentation of the föhn from the synoptic scale to the scale of the valleys, with sufficient spatial and time resolution to analyse the processes governing the evolution of föhn development and its spatial structure. During the Mesoscale Alpine Programme (MAP) field experiment (Bougeault et al. 2001), the target area for föhn studies was located in the Rhine Valley between the city of Chur and Lake Constance (Fig. 1).

The FORM ('FOehn in the Rhine Valley during MAP') programme was designed to improve the understanding and forecasting of the life cycle of föhn-related phenomena, including their three-dimensional structure and associated boundary-layer processes. In the framework of the FORM programme, Drobinski et al. (2001a) investigated theoretically and experimentally, the small-scale dynamical processes that explain how air blows in the Rhine Valley (hereafter, RV1 is used for the lower part of the Rhine Valley and RV2 for the upper part, see Fig. 1(b)) and the Seez Valley (hereafter called SV, see Fig. 1(b)), during föhn and in the absence of föhn. Drobinski et al. (2003) used the rawinsonde observations acquired during the whole MAP Special Observing Period (SOP) to connect the small-scale circulation in the FORM target area with mechanical or thermal forcing at synoptic or local scales.

The present study investigates the spatial scale interactions during a south föhn event in the FORM target area between 29 October 1999 and 31 October 1999, i.e. during Intensive Observing Period (IOP) 12 of the MAP field experiment. This south föhn event had the advantage of presenting clear separate development stages, each lasting several hours, with no intermittent breakdowns (unlike during IOPs 5, 8, 9 and 10) and could thus be reliably and accurately documented with time and space resolutions never achieved before, from its onset until its breakdown. This paper focuses on several points that in fact motivated the deployment of this unique and very dense instrumental set-up during MAP, to study the processes related to föhn in this region. The key issues addressed in this study are:

- The diurnal cycle of a south föhn event, i.e. the mechanism of temporal and spatial evolution and cessation of föhn in this complex valley system on a local scale.

- The three-dimensional structure of the föhn flow from synoptic to local scale.

- The interaction between low-level and mid-tropospheric föhn flow on the scale of the large Alpine valleys. 


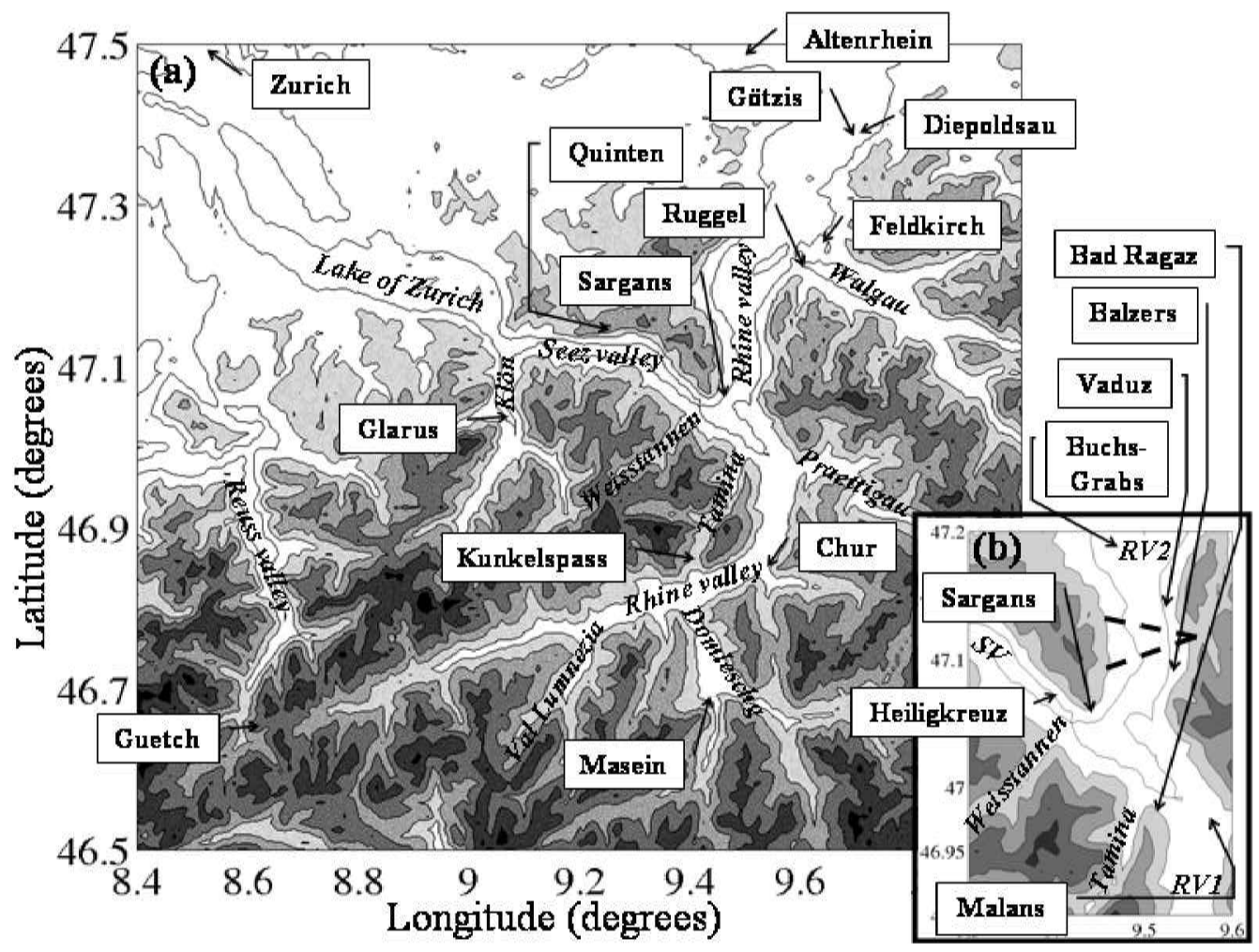

Figure 1. Topography of the FORM (see text) target area (a), zoomed on the region of interest on a local scale (between 9.3 and $9.6^{\circ} \mathrm{E}$ and 46.9 and $47.2^{\circ} \mathrm{N}$ ) (b), which is also the most instrumented area (see section 2). The isocontour increment is $500 \mathrm{~m}$ from $500 \mathrm{~m}$ altitude to $3000 \mathrm{~m}$ altitude. Italic writing indicates names of valleys, while legends in the boxes are the name of cities. SV, RV1 and RV2 correspond to the Seez Valley, the lower Rhine Valley and the upper Rhine Valley, respectively. The dashed straight lines indicate the scintillometer light beams. The scintillometer transmitters are located in Triesenberg (on the eastern side of RV2), the receivers in Flusa and Ergellen (on the western side of RV2).

This study makes use of the data collected in the FORM target area by the dense rawinsonde and surface station network, scintillometers and a ground-based Doppler lidar. At a larger scale, the rawinsonde and surface station networks provide the synoptic setting for föhn occurence, and constant-volume balloons provide information on the wave activity and the intensity of turbulence associated with the föhn event. In addition, mesoscale numerical simulations are used to investigate the role of the tributary valleys in the föhn flow structure in the FORM target area, and the coupling between the föhn flow and the wave activity.

Following the introduction in section 1, the instrumental set-up and the numerical model Meso-NH are presented in sections 2 and 3, respectively. Scale interactions are studied using a downscaling approach from the synoptic environment favourable to south föhn in the Rhine Valley (section 4) and the mesoscale processes forcing the flow at the Rhine Valley and tributary scale (section 5) to the development of the föhn flow at local scale in the FORM target area (section 6). This study is conducted for the different stages of development of the IOP 12 föhn episode. 


\section{INSTRUMENT SET-UP}

(a) At the scale of the valley

(i) Rawinsonde and surface station network. The valley flow structure in the FORM target area was investigated using rawinsonde stations in Buchs-Grabs, Diepoldsau, Heiligkreuz, Malans and Masein.

Surface measurements of pressure, temperature, humidity and sometimes wind speed and direction were recorded at the stations in Altenrhein, Chur, Quinten and Vaduz (Fig. 1) and were used to investigate the dynamical processes driving the flow structure in the FORM target area and to compute local pressure gradients.

(ii) Scintillometers. Two scintillometers with three sensors arranged in the shape of the letter L (Poggio et al. 2000) were located in RV2. The scintillometer transmitters were located in Triesenberg, the receivers in Flusa and Ergellen (see Fig. 1(b)) at about $500 \mathrm{~m}$ above ground level (AGL), i.e. $1000 \mathrm{~m}$ above sea level (ASL). Assuming a homogeneous wind field in the whole area between the light beams, this V-shaped arrangement of the light beams allowed the simultaneous measurement of the vertical and horizontal components of the wind field. This method was used to document the strong föhn wind storms of MAP IOP 8 to 10 (i.e. 20 to 24 October 1999) (Furger et al. 2001).

(iii) Transportable wind lidar. The transportable wind lidar (TWL) was located near Bad Ragaz in Vilters (see Fig. 1). The TWL provides wind radial-velocity measurements along the line of sight. During the MAP SOP, scans were performed by sweeping the azimuth angle from $262^{\circ}$ (in the direction of RV1) to $142^{\circ}$ (in the direction of SV), and the elevation from $4^{\circ}$ to $28^{\circ}$ with increments in elevation and azimuth of $2^{\circ}$ and $5^{\circ}$, respectively (see Drobinski et al. 2001 a for more details).

\section{(b) At the synoptic scale}

(i) Rawinsonde and surface station network. The synoptic pressure gradients parallel and perpendicular to the Alpine ridge are computed from the surface measurements collected hourly in Lugano, Vaduz and Zurich. In addition, the evolution of the surface wind in the Reuss Valley at the Guetsch station (Fig. 1(a)) is analysed and the data collected by the rawinsondes launched from the operational meteorological station in Milano-Linate are used to document the upstream flow and stability on the southern part of the Alpine ridge.

(ii) Constant-volume balloons. During IOP 12, constant-volume balloons (CVBs) were launched from Ispra (Italy) located near the Lago Maggiore to document the dynamics of the isopycnic airflow (pressure, wind intensity and direction, temperature and humidity content) and particularly the characteristics of orographic waves and trapped lee waves (location, amplitude, period, intensity) (e.g. Koffi et al. 2000).

\section{(c) Surface-data analysis}

Pressure and temperature data from the surface stations (including those collocated with the upper-air stations) were interpolated at surface level to a regular grid with a spacing of $2 \mathrm{~km}$ using the Vienna Enhanced Resolution Analysis (VERA) algorithm. This algorithm is a further development of the method described in Steinacker et al. (2000) and has many similarities to the thin-plate spline method. 


\section{MODEL DESCRIPTION}

The Meso-NH model solves the non-hydrostatic and anelastic equation system (Lafore et al. 1998). The turbulence scheme is uni-dimensional in the vertical and is based upon the physical mixing length of Bougeault and Lacarrère (1989). The convection and radiation schemes, as well as the parametrization of land surface processes are described in Bechtold et al. (2001), Mocrette (1991) and Noilhan and Planton (1989), respectively.

A $36 \mathrm{~h}$ simulation initialized at 0600 UTC on 29 October 1999 was completed using stationary $2 \mathrm{~km}$ and $8 \mathrm{~km}$ resolution domains nested within a $32 \mathrm{~km}$ domain using twoway interfaces (Stein et al. 2000). The initial and coupling fields were generated by first interpolating the French analysis Action des Recherche Petite Échelle et Grande Échelle (ARPEGE) data available every 6 hours to the model grid. The vertical grid is made of 50 levels with a mesh stretched between 60 and $600 \mathrm{~m}$. To ensure a good description of the atmospheric boundary layer, 12 levels are used below $1000 \mathrm{~m}$. The size of the first nine meshes is less than $100 \mathrm{~m}$. Above $6400 \mathrm{~m}$, the mesh size is constant and set to $500 \mathrm{~m}$. An absorbing layer is set above $14000 \mathrm{~m}$. The top of the domain is located at $21400 \mathrm{~m}$.

In the following, Meso-NH simulations are validated and used to provide the threedimensional environment necessary for the interpretation of the measurements.

\section{IOP 12 SYNOPTIC ENVIRONMENT}

The föhn case of IOP 12 (30 October-31 October 1999) is also known as the 'Sahara dust föhn' of the MAP SOP. Ahead of a trough west of the Iberian peninsula on 29 October 1999, very warm air from north-western Africa was advected to southern France (Pau, foothill of the French Pyrenees, reported $29{ }^{\circ} \mathrm{C}$ ). A branch of this warm air also reached the regions north of the Alps. In Geneva (south-western Switzerland) large amounts of dust from the Sahara were registered on 29 October 1999 during the day. Also, at the MAP operations centre in Innsbruck a probe of Sahara dust was collected. Temperature maxima in the FORM target area reached a remarkable $20^{\circ} \mathrm{C}$. The Iberian trough moved north-eastward and joined the strong westerly jet over the north-east Atlantic (Fig. 2).

The surface pressure field was initially dominated by a large anticyclone with its centre over eastern Europe. This anticyclone moved further to the south-east. This movement, together with the trough moving towards the European continent, caused the large-scale mid-tropospheric flow to back from the west on 29 October in the afternoon to the south-west during the evening. In the same time interval, the cross-Alpine pressure difference increased to about $6 \mathrm{hPa}$ within 6 hours (Fig. 3). This strong amplification of the pressure contrast is called the 'föhn knee' (Brinkmann 1971). The situation did not change much during the second half of the night. Until noon on 30 October 1999 the mid-tropospheric flow was reinforced and the cross-Alpine pressure difference increased to $8.5 \mathrm{hPa}$ around $1200 \mathrm{UTC}$. At about the same time, föhn started. It ended when the cold front associated with the Iberian trough reached the target area shortly after midnight of 30/31 October 1999.

Precipitation during the whole episode was weak and spatially inhomogeneous. Very light precipitation in the northern parts of the target area started after the passage of the cold front after midnight of 30/31 October 1999. The first rain observations are from Diepoldsau and Heiligkreuz in the FORM target area (Fig. 1(b)) at 0100 UTC.

There is a considerable annual cycle in the characteristics of föhn flow. The mean cross-Alpine pressure difference (Vaduz-Lugano) during the föhn cases in September 
29 Oct. 199918 UTC

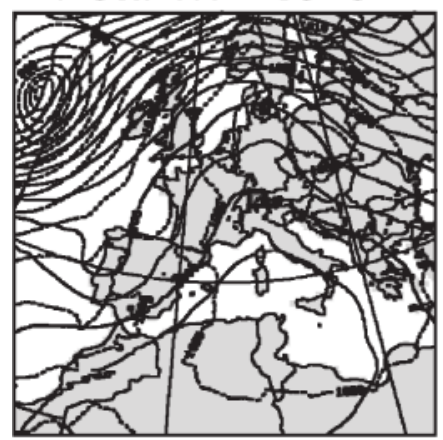

30 Oct. 1999 12UTC

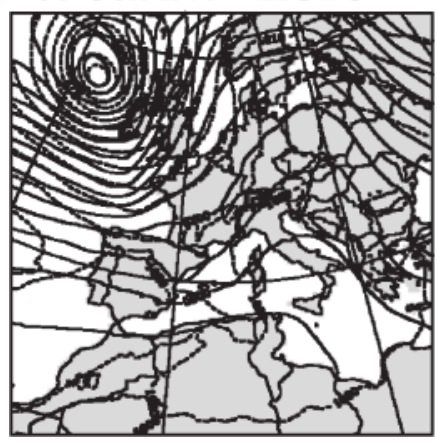

30 Oct. 1999 00UTC

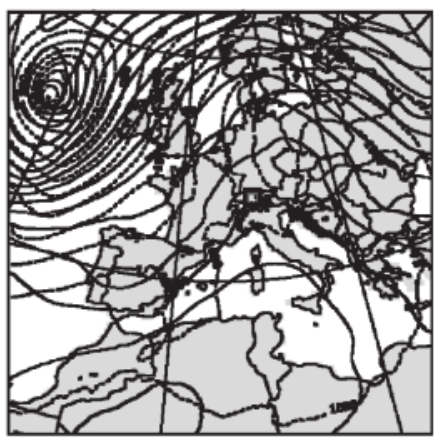

30 Oct. 1999 18UTC

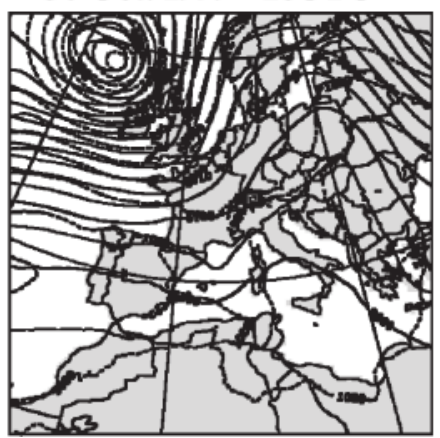

30 Oct. 1999 06UTC

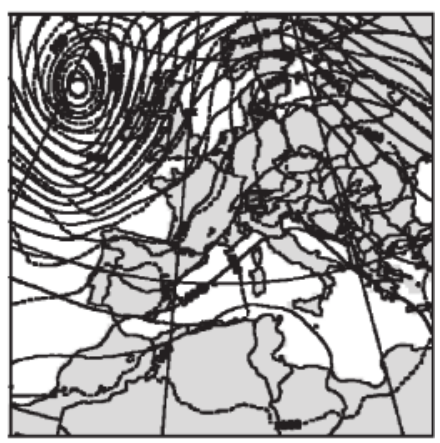

31 Oct. 1999 00UTC

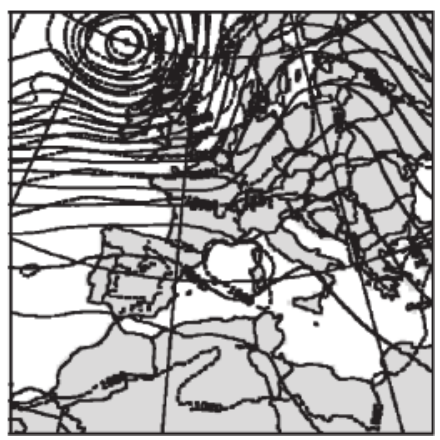

Figure 2. Synoptic situation for Intensive Observing Period 12 in 6-hourly intervals from ARPEGE analyses. Solid lines and shaded area: geopotential height at $500 \mathrm{hPa}$, with an increment of $50 \mathrm{~m}$; dashed lines: mean-sealevel pressure with an increment of $5 \mathrm{hPa}$. The rectangle indicates the location of the FORM target area (see text).

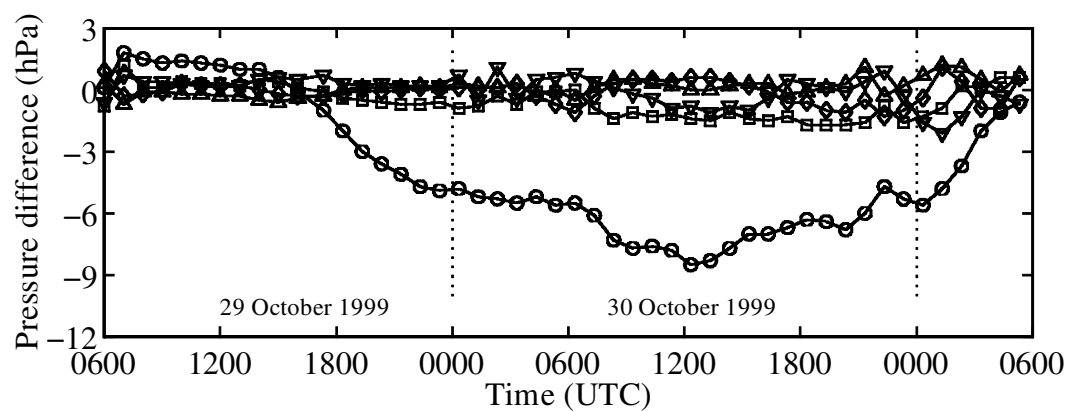

Figure 3. Pressure differences between various stations. The pressure differences are normalized to the mean of the whole Mesoscale Alpine Programme Special Observing Period. Vaduz-Lugano, cross-Alpine (o); VaduzChur, parallel to RV1 $(\square)$; Altenrhein-Vaduz, parallel to RV2 $(\diamond)$; Quinten-Vaduz, perpendicular to the Rhine Valley $(\triangle)$; Vaduz-Zurich, parallel to the northern slope of the Alps $(\nabla)$.

and early October 1999 varied between $-3.1 \mathrm{hPa}$ and $-6.6 \mathrm{hPa}$, but increased to values between $-4.9 \mathrm{hPa}$ and $-9.3 \mathrm{hPa}$ during the cases between mid October and mid November. For a comprehensive comparison of all föhn cases observed during the MAP SOP, see Steinacker et al. (2003). To take into account the annual cycle, the comparison of the IOP 12 föhn case with other föhn events of the MAP SOP is restricted to those five cases which occurred between mid October and mid November. With respect to the 
cross-Alpine pressure difference, the IOP 12 case was not as strong as the three preceding cases. But it was the case with the highest mean potential-temperature difference across the Alps $(9.0 \mathrm{~K})$. Although there are only a few simultaneous observations, there is a clear indication of a pronounced negative height difference at $700 \mathrm{hPa}$ between Diepoldsau (situated to the north of the FORM target area) and Milano. Comparably strong differences were observed during only one other case (IOP 5) during the SOP. During IOP 12, the flow direction at the Alpine crest was very similar to during the other IOPs, but the wind speed was up to $10 \mathrm{~m} \mathrm{~s}^{-1}$ lower than during the strongest cases.

\section{DyNAMiCAL PROCESSES OF THE FÖHN LIFE CYCLE AT THE MESOSCALE}

The föhn touches the ground in the Rhine Valley when the cross-Alpine pressure difference is larger than about $6 \mathrm{hPa}$ (Fig. 3), i.e. on 30 October 1999 at about 0900 UTC, and lasts until 31 October 1999 at 0310 UTC. This pressure difference value is comparable to that observed during IOPs 2, 8, 9 and 10 and indicates that the blocking effect and the heating due the synoptic situation and föhn are strong (Steinacker et al. 2003). In fact, substantial heating and drying (exceeding föhn criteria) is observed in Vaduz (Figs. 4(c) and (d)) in the FORM target area (Fig. 1(b)). This penetrating föhn period is associated with a south/south-westerly upper-level flow, channelled in the north-south oriented parts of the Rhine Valley (Fig. 4(b)). Preceding the penetrating föhn, a shallow föhn phase is observed in the night between 29 and 30 October 1999, during which a strong cross-Alpine pressure gradient allows the deflection of the westerly upper-level flow within the Rhine Valley (Fig. 4(b), Seibert 1990). However, katabatic drainage flow from the longitudinal (i.e. north-south oriented) and transverse (i.e. east-west oriented) tributaries of the Rhine Valley, prevents the föhn penetrating down to the surface of the Rhine Valley (Fig. 4, see section 6). The term 'sandwich föhn' might thus be appropriate to describe this flow (Vergeiner and Mayr 2000).

One purpose of this section is to study the upper-level flow deflection mechanism during the shallow föhn. In fact, the previous studies on the channelling effect of the föhn flow by major Alpine valleys considered north-south oriented portions of Alpine valleys. In the FORM target area, the Rhine Valley has a very complex shape: below $46.8^{\circ} \mathrm{N}$, the Rhine Valley is oriented west-east while above $46.8^{\circ} \mathrm{N}$, it has a more southnorth orientation up to Lake Constance. Several major valleys merge with the Rhine Valley, these are the Val Lumnezia, the Domleschg, the Praettigau, the Seez Valley and the Walgau. Also, at the bifurcation between the Rhine and Seez Valleys, the Tamina gorge and the Weisstannen Valley play an important role. In other words, the Rhine Valley cannot be considered as a transect in the Alpine ridge and all these tributaries should play a role in the circulation of the föhn flow in the FORM target area. As a consequence, a second objective in this section is to examine the role of the Alpine valley network in directing the föhn flow towards the FORM target area from its early stage of development (shallow föhn) until its breakdown.

\section{(a) Sandwich shallow föhn}

On the windward side, the Po Valley and the valleys in the southern Alps are filled with a stably stratified, relatively cool air mass. The stability is concentrated in an inversion layer between $2000 \mathrm{~m}$ and $3000 \mathrm{~m}$. In the Po Valley a pronounced easterly flow is observed below the inversion providing evidence of blocking by the barrier (Fig. 5). In fact, due to the topography of the Alps and the Appennines, a convergence is to be expected in the region of Milano (Seibert 1990). The air mass 

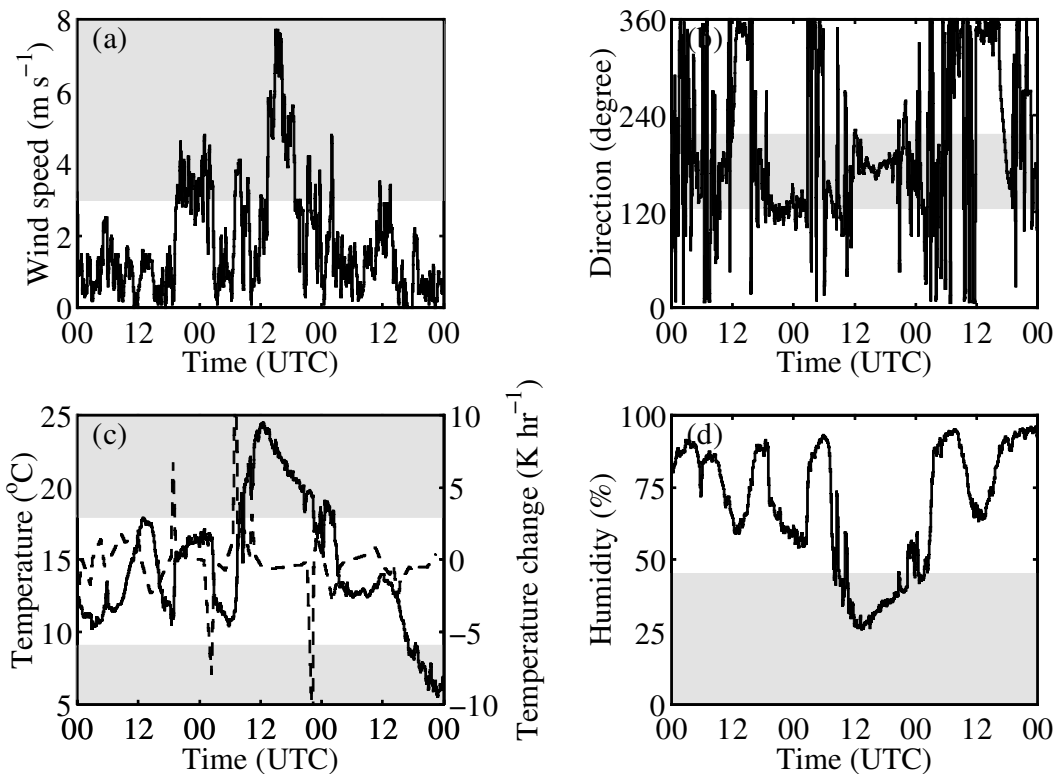

Figure 4. Time series of (a) surface wind speed, (b) wind direction, (c) temperature (solid line) and temperature growth (dashed line), and (d) relative humidity measured at Vaduz. The shaded areas show the range for wind speed $\left(\geq 3 \mathrm{~m} \mathrm{~s}^{-1}\right)$ and direction $\left(\geq 125^{\circ}\right.$ and $\left.\leq 215^{\circ}\right)$, temperature growth $\left(\geq 3 \mathrm{~K} \mathrm{~h}^{-1}\right.$ for the onset of föhn and $\geq-6 \mathrm{~K} \mathrm{hr}^{-1}$ for the end of föhn), and relative humidity ( $\left.\leq 45 \%\right)$ when föhn occurs at Vaduz. These criteria must be met simultaneously.

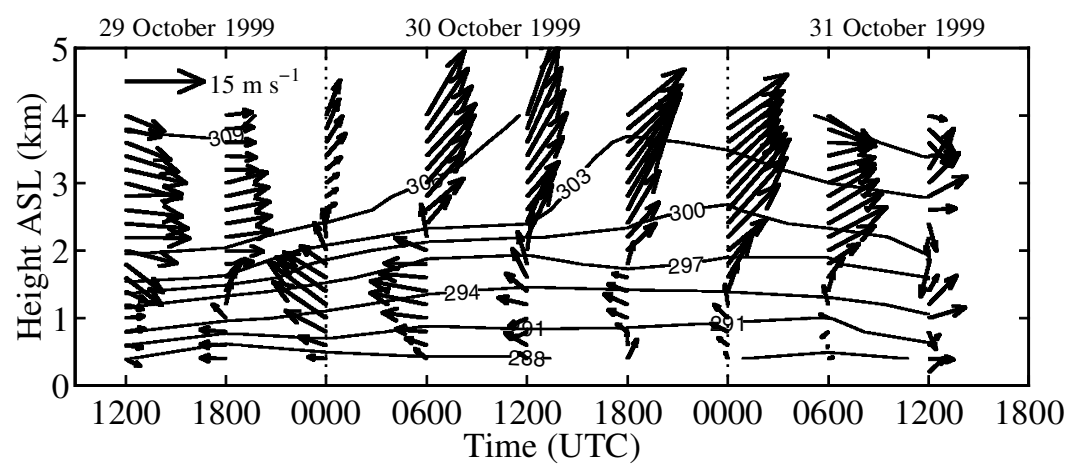

Figure 5. Time series of rawinsonde ascents at Milano-Linate. The arrows indicate the horizontal wind speed and direction, the solid lines display the isentropes of potential temperature. Narrow spacing indicates stable stratification, wide spacing indicates unstable stratification.

below the inversion remains in the south and is not part of the shallow föhn flow. The controlling parameters of upstream blocking are the Froude number, $F r=U / N h$, and the cross-mountain Rossby number, $R o=U / f L_{\mathrm{h}}$ (Pierrehumbert and Wyman 1985) ( $U$ is the mean upstream wind, $N$ the Brunt-Väisälä frequency, $h$ the ridge height, $L_{\mathrm{h}}$ the half-width of the mountain, and $f$ the Coriolis parameter). The parameters $F r$ and $R o$ are found to be equal to 0.26 and 1.62 for $h=2500 \mathrm{~m}$ and $L_{\mathrm{h}}=80 \mathrm{~km}$, respectively (Table 1), which predict strong blocking, the Coriolis force limiting the upstream extent of the decelerated layer. 

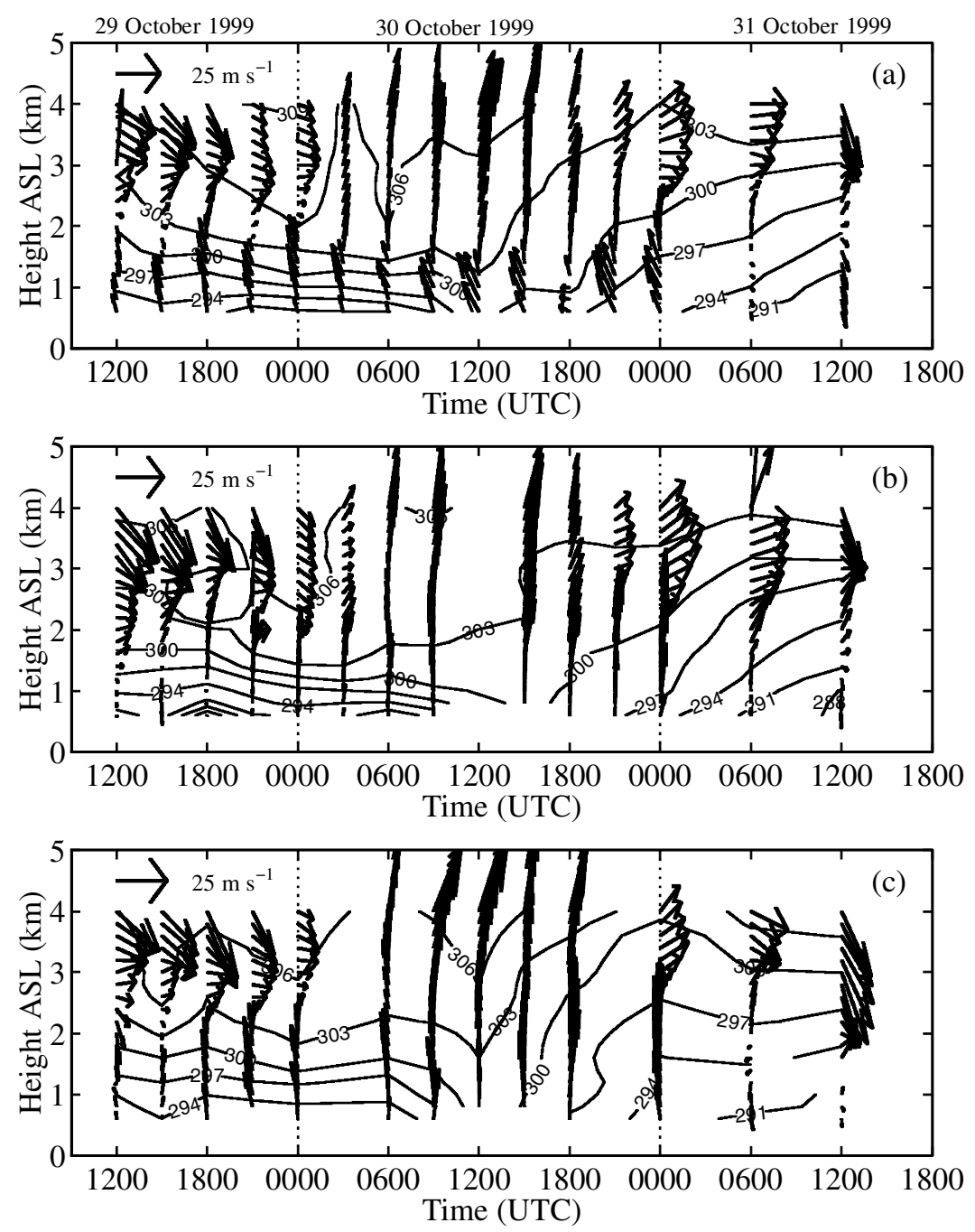

Figure 6. Same as Fig. 5 at (a) Heiligkreuz, (b) Buchs-Grabs, and (c) Malans.

In the northern Alpine valleys, the air shows little motion during the shallow föhn (see Figs. 4 and 6). Figure 6 shows a strong decoupling between lower- and upperlevel flows. This is clearly visible with a highly stable stratification downstream, a layered structure of the humidity field (not shown) and very different wind speeds and directions between the higher vertical levels of the atmosphere and the channelled flow. The observations show that on 29 October 1999 after 1700 UTC, the synoptic flow blows from the west/south-west while the flow within the Rhine Valley blows from the south in RV1 (Fig. 6).

The reason for the deflection of the westerly upper-level flow is a deceleration of the flow within the main longitudinal tributaries (i.e. the Reuss Valley, Val Lumnezia and the Domleschg, see Fig. 1(a)), due to the cross-section through which the flow has to stream. The retardation disturbs the equilibrium between the horizontal pressure gradient and the Coriolis force by diminishing the latter. Consequently, the flow is deflected in the 
(a)

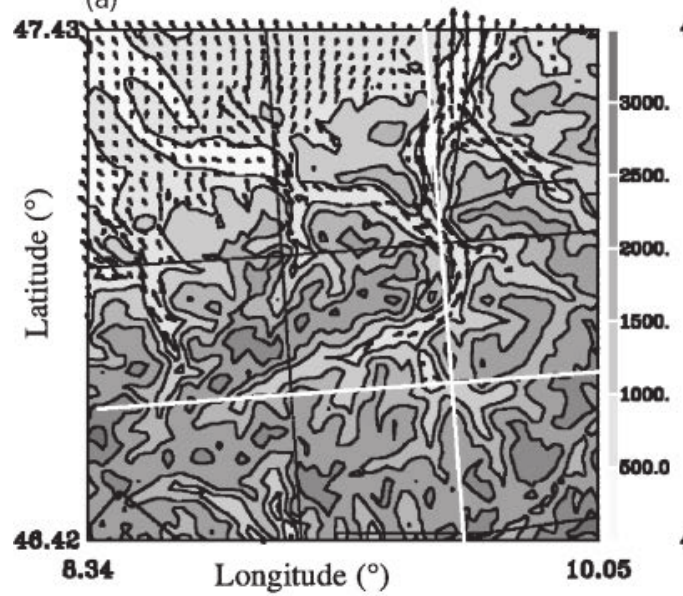

(b)

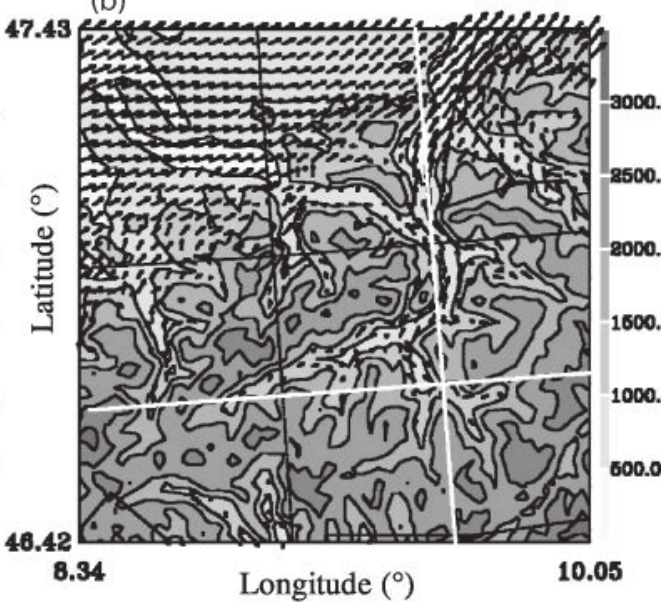

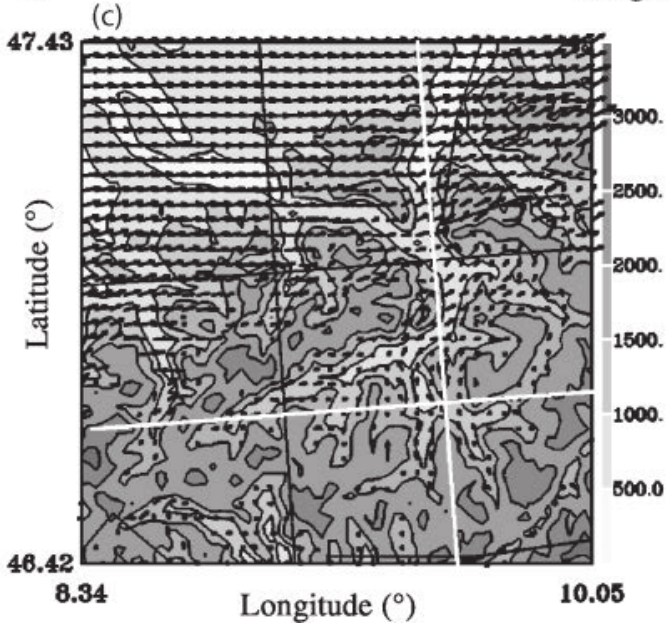

Figure 7. $2 \mathrm{~km}$ resolution horizontal wind field at (a) $1000 \mathrm{~m}$ above sea level (ASL), (b) $1500 \mathrm{~m}$ ASL, and (c) $2000 \mathrm{~m}$ ASL, as obtained from Meso-NH numerical simulations on 29 October 1999 at 1800 UTC.

direction of the increasing imposed large-scale pressure gradient. However, since the air is forced to flow parallel to the bordering mountains, only the component along the valley of the large-scale pressure gradient can be effective. This causes the channelling of the flow (Sprenger and Schär 2001). The Meso-NH wind field on 29 October 1999 at 1800 UTC shows evidence of weak southerly wind through the Reuss Valley and Domleschg (Figs. 8 and 7). In the Reuss Valley, the southerly flow is confined at the bottom of the valley while on the eastern flank of the Domleschg (which feeds RV1 near the city of Chur) the southerly flow extends up to the crest of the mountain ridge. Similarly to the idealized numerical studies of Sprenger and Schär (2001), the Meso-NH isentropes as well as the isotachs shown in Fig. 8 separate from the topography over the Reuss Valley, and exhibit a hydraulic-jump-like feature with a strong deceleration of the horizontal wind (about $-6 \mathrm{~m} \mathrm{~s}^{-1}$ ) (e.g. Drobinski et al. 2001b,c) and a complex wave train that dissipates rapidly eastwards.

The development of the southerly flow at surface height (10 m AGL) at the Guetsch station situated on a pass near the Alpine crest at the southern end of the Reuss Valley (Fig. 1(a)) is displayed in Fig. 9: it shows a northerly wind from 0400 UTC 
(a)

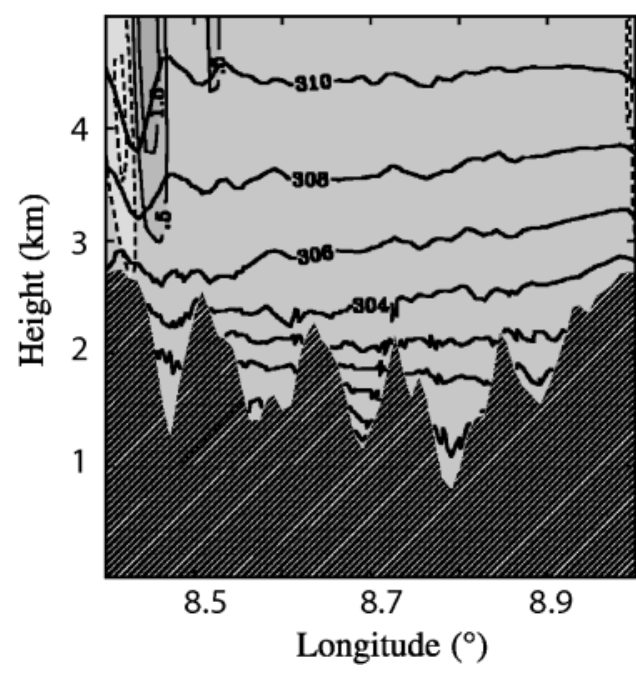

(b)

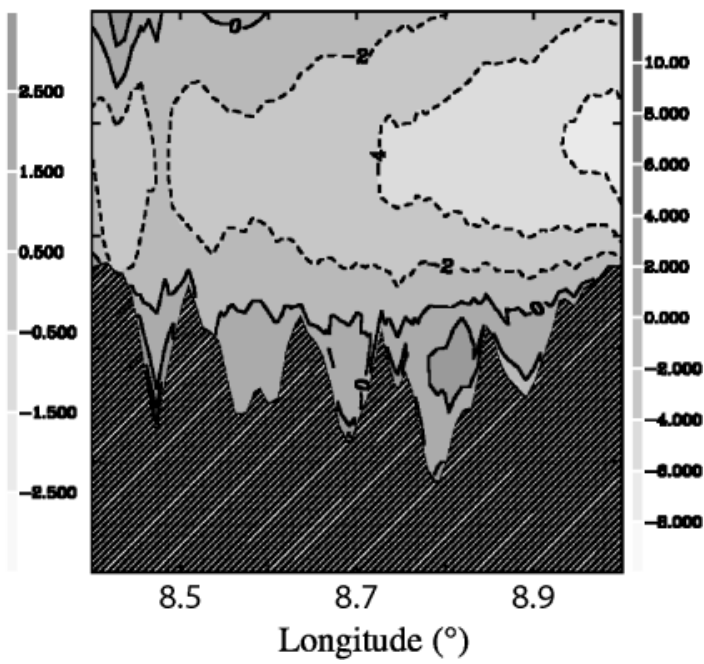

Figure 8. Vertical cross-section of Meso-NH (a) vertical velocity (grey scale, $\mathrm{m} \mathrm{s}^{-1}$ ) and potential temperature (isentropes in solid line, K) and (b) south-north wind component (grey scale, $\mathrm{m} \mathrm{s}^{-1}$ ) on 29 October 1999 at 1800 UTC between $\left(8.4^{\circ} \mathrm{E}, 46.7^{\circ} \mathrm{N}\right)$ and $\left(10.0^{\circ} \mathrm{E}, 46.7^{\circ} \mathrm{N}\right)$. This section transects from left to right (i.e. west to east), the Reuss Valley, the Rhine Valley, Val Lumnezia and two branches of the Domleschg.
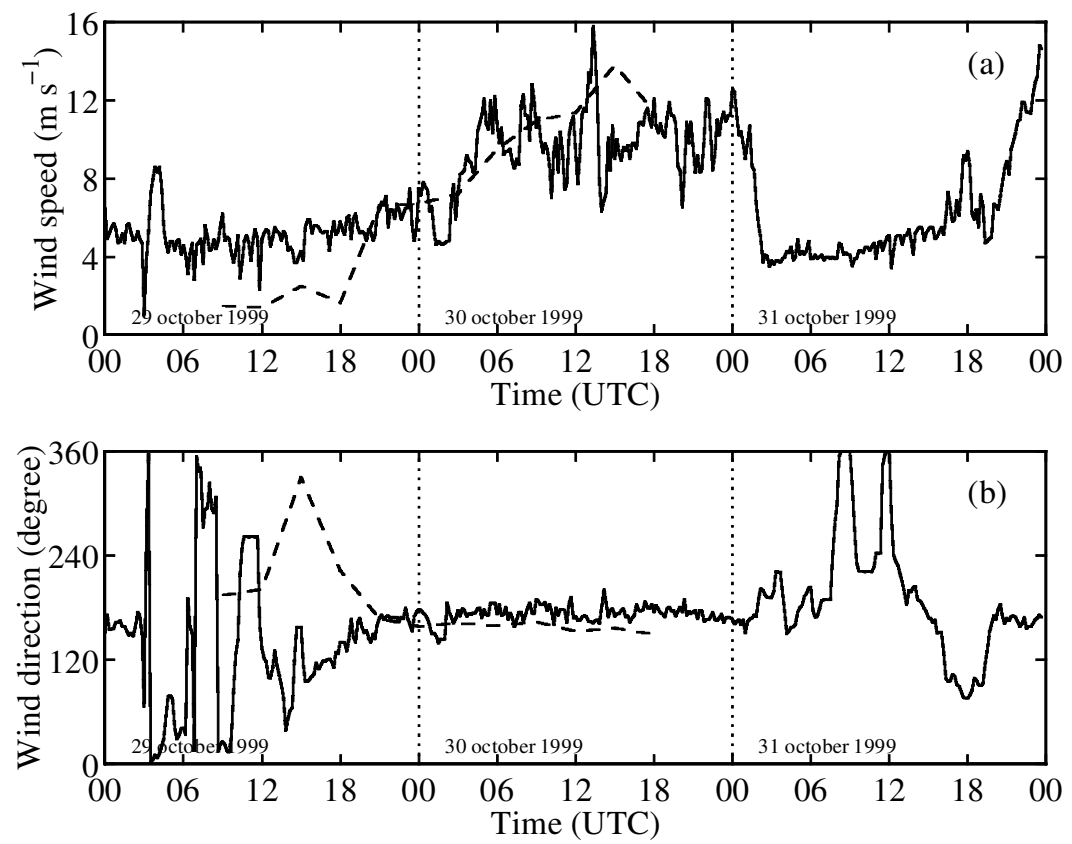

Figure 9. Time evolution of (a) wind speed and (b) direction, measured (solid line) and simulated (dashed line) at the surface at the Guetsch station in the Reuss Valley (Fig. 1(a)) from 29 October 1999 at 0000 UTC to 31 October 1999 at 2300 UTC. 
TABle 1. Scale analysis of the Flow in the Reuss Valley, Val Lumnezia and DOMLESCHG

\begin{tabular}{|c|c|c|c|}
\hline & Reuss Valley & Val Lumnezia & Domleschg \\
\hline \multicolumn{4}{|l|}{ Geometrical settings } \\
\hline Height of the crest $H(\mathrm{~m})$ & 2500 & 2100 & 2100 \\
\hline Depth of the valley $\Delta H(\mathrm{~m})$ & 1100 & 900 & 1200 \\
\hline Length of the valley $L(\mathrm{~km})$ & 45 & 16 & 32 \\
\hline Width of the valley $l(\mathrm{~km})$ & 5 & 7 & 6 \\
\hline $\begin{array}{l}29 \text { October } 1999 \text { at } 1800 \mathrm{UTC} \\
f=10^{-4} \mathrm{~s}^{-1}, \mathrm{~d} \theta / \mathrm{d} z=0.013 \mathrm{~K} \mathrm{~m}^{-1}, \\
\quad N=2.10 \times 10^{-2} \mathrm{~s}^{-1} \text { and } U=13\end{array}$ & & & \\
\hline Along-valley wind speed $v\left(\mathrm{~m} \mathrm{~s}^{-1}\right)$ & 3 & 1 & 3 \\
\hline Along-valley Rossby number $R_{l}$ & 6.00 & 1.42 & 5.00 \\
\hline Cross-valley Rossby number $R_{L}$ & 0.07 & 0.21 & 0.17 \\
\hline Dimensionless valley depth $\widetilde{\Delta H}$ & 1.78 & 1.45 & 1.94 \\
\hline Rossby radius of deformation $l_{R}(\mathrm{~km})$ & 273 & 231 & 315 \\
\hline $\begin{array}{l}30 \text { October } 1999 \text { at } 1200 \mathrm{UTC} \\
f=10^{-4} \mathrm{~s}^{-1}, \mathrm{~d} \theta / \mathrm{d} z=0.007 \mathrm{~K} \mathrm{~m}^{-1} \text {, } \\
\quad N=1.54 \times 10^{-2} \mathrm{~s}^{-1} \text { and } U=17\end{array}$ & & & \\
\hline Along-valley wind speed $v\left(\mathrm{~m} \mathrm{~s}^{-1}\right)$ & 12 & 4 & 8 \\
\hline Along-valley Rossby number $R_{l}$ & 24.00 & 5.71 & 13.33 \\
\hline Cross-valley Rossby number $R_{L}$ & 0.29 & 0.86 & 0.47 \\
\hline Dimensionless valley depth $\widetilde{\Delta H}$ & 1.00 & 0.82 & 1.09 \\
\hline Rossby radius of deformation $l_{R}(\mathrm{~km})$ & 200 & 169 & 231 \\
\hline
\end{tabular}

The mean lapse rate $\mathrm{d} \theta / \mathrm{d} z$, the Brunt-Väisälä frequency $N$, and the mean upstream wind $U$ are obtained from the upstream sounding in Milano.

to about 1200 UTC that veers slowly to the south and stabilizes at about 1800 UTC. The wind speed is nearly constant and equal to $5 \mathrm{~m} \mathrm{~s}^{-1}$ and starts to intensify at 1800 UTC. The Meso-NH simulations catch with good accuracy the development of the southerly flow in the Reuss Valley but underestimate the wind intensity and generate large discrepancies in the wind direction before 1800 UTC on 29 October 1999.

Horizontal cross-sections of Meso-NH horizontal wind fields show that near the surface, the flow at Chur is fed by the katabatic flow from south-western RV1 (Fig. 7(a)). At higher levels (Figs. 7(b) and (c)), the air from the Domleschg partly goes straight to the north over the Kunkelspass (which is only $700 \mathrm{~m}$ AGL, i.e. is about the same height as the crest of the gorge near Rothenbrunnen inside the Domleschg), and partly towards Chur in RV1. The reason why Val Lumnezia does not deflect significantly the westerly upper-level flow is the short length of the valley (Table 1) since the maximum meridional velocity behaves as $L^{1 / 2}$ where $L$ is the length of the valley (Sprenger and Schär 2001). At $1500 \mathrm{~m}$ ASL, katabatic drainage flow blows from the transverse Praettigau. One can note a strong intensification of the flow in RV2 near Feldkirch where the flow originating from the splitting of the flow at the bifurcation of the Rhine and Seez Valleys merges with flow blowing from the east-west oriented Walgau. At the bifurcation between the Rhine and Seez Valleys, the flow comes from the Tamina gorge and RV1 (the flow first splits between these two valleys near Kunkelspass) and splits between SV and RV2.

The detailed three-dimensional flow structure shown in Fig. 7 is in good agreement with the TWL observations (Fig. 10). The upper-level flow backs slowly from the west (Fig. 10(h)) to the south-west (Fig. 10(1)). At 1700 UTC, evidence of flow splitting is observed at $1000 \mathrm{~m}$ ASL with air blowing away from the TWL (hot colours) in SV and RV2. A strong transverse radial-velocity shear is visible in SV with a near-wall jet (about $8 \mathrm{~m} \mathrm{~s}^{-1}$ ) at the northern wall of SV, while the wind speed is very weak at the southern wall of SV. This could be due to wall separation and drainage outflow from 


\section{Radial velocity $(\mathrm{m} / \mathrm{s})$}

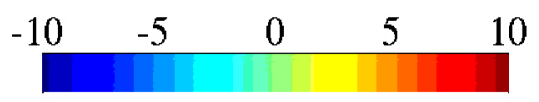

\section{October 1999 - 1200 UTC}
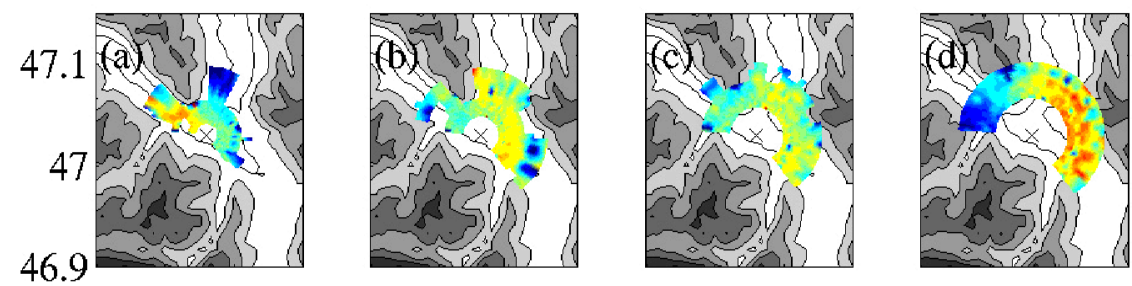

\section{October $1999-1700$ UTC}
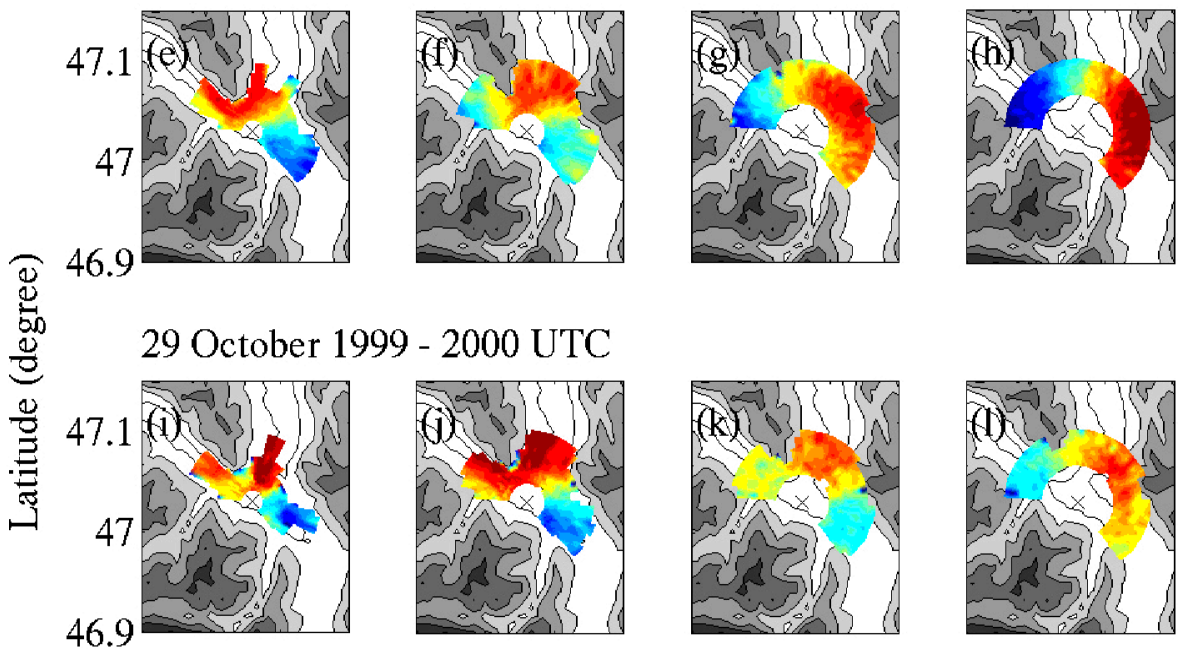

\section{October 1999 - 1200 UTC}
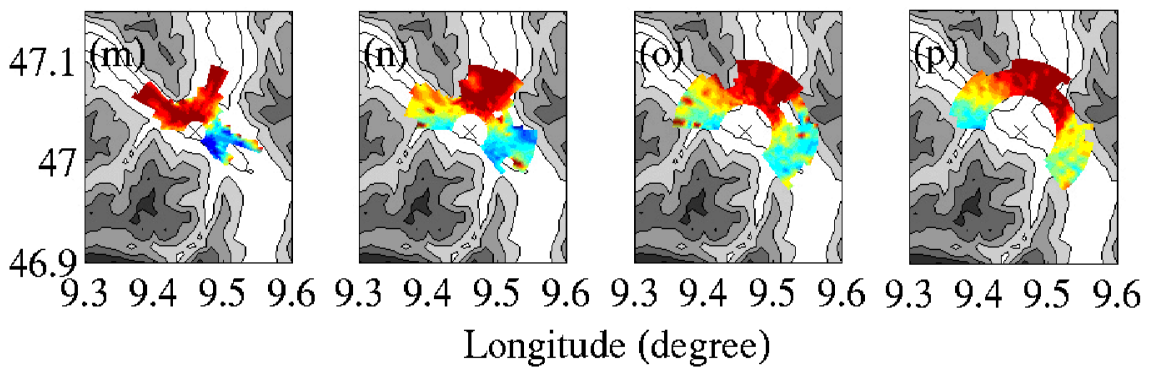

Figure 10. Transportable Wind Lidar (TWL) radial-velocity field at $1000 \mathrm{~m}$ above sea level (ASL, first column), $1500 \mathrm{~m}$ ASL (second column), $2000 \mathrm{~m}$ ASL (third column) and $2500 \mathrm{~m}$ ASL (fourth column) retrieved from raster scans on 29 October 1999 at about 1200 UTC (first row), 1700 UTC (second row), 2000 UTC (third row) and on 30 October 1999 at about 1200 UTC (fourth row). Positive (negative) radial velocities correspond to air blowing away from (towards) the TWL. Absence of colour means no reliable data (low signal to noise ratio, presence of topography). The data quality-control procedure is explained in Dabas et al. (1999). The marker $\times$ indicates the location of the TWL. SV, RV1 and RV2 denote the Seez Valley, the lower Rhine Valley towards Chur, and the upper Rhine Valley towards Lake Constance, respectively. 
the Weisstannen Valley (Fig. 7) and could explain why people living along the southern slope of SV report unexpectedly weak winds during föhn. At $1500 \mathrm{~m} \mathrm{ASL}$, the air is almost fully deflected in RV2, while a north-westerly flow blows in SV with a very thin layer of weak south-easterly flow at the northern sidewall of SV. At 2000 UTC, Fig. 10 (third row) shows that the layer where flow splitting occurs between the Rhine and Seez Valleys deepens as flow splitting is visible at $1000 \mathrm{~m}$ and $1500 \mathrm{~m}$ ASL. The valley flow and the flow above the crest are now clearly decoupled. Drobinski et al. (2003) showed that flow splitting between the Rhine and Seez Valleys occurs during föhn events or at night. Figure 7 shows that westerly/north-westerly flow blowing from the Lake of Zurich and from the Klön Valley near Glarus (strong thermal gradient at this altitude in these valleys) prevents the air coming from RV1 to penetrate further in SV.

To provide some insight into the dynamics of the flow in the longitudinal tributaries of the Rhine Valley, the down-valley Rossby number $R_{l}=v / f l$ and the cross-valley Rossby number $R_{L}=l^{2} / L^{2} R_{l}$ (where $v$ is the along-valley wind speed, $l$ and $L$ the cross- and along-valley length-scales and $f$ is the Coriolis parameter) are computed from Table 1 . In the three valleys, $R_{L} \ll 1$ suggesting that the flow is in geostrophic balance in the valley, i.e. that the pressure gradient normal to the valley axis is balancing the Coriolis force associated with the along-valley component of the winds. As the largescale pressure gradient is oriented along the axis of the three valleys, then as $R_{l}>1$, it will be balanced by the ageostrophic acceleration of the flow down the axis of the valley and gap winds will result (Overland 1984). As the three valleys are narrow, i.e. $l$ is lower than the Rossby radius of deformation $l_{R}=N \Delta H / f$ ( $\Delta H$ is the depth of the valley and $N$ the Brunt-Väisälä frequency), they favour rapid transitions and hydraulictype responses near the valley exits. The dimensionless valley depths $\widetilde{\Delta H}=N \Delta H / U$, which discriminate the nature (linear versus nonlinear) of the flow regime in the valley are close to the critical dimensionless mountain height $(\widetilde{\Delta H} \sim \mathrm{O}(1))$ and thus substantial nonlinear effects are expected (such as the hydraulic jump) (Sprenger and Schär 2001).

\section{(b) Penetrating föhn in the Rhine Valley}

On 30 October 1999 at 1200 UTC, when föhn reaches the Rhine Valley, the upstream upper-level flow veers to the south/south-west and stability decreases as wider spacing between the isentropes is visible in Fig. 5. The vertical extension of the blocking region also narrows as the Froude number increases $(F r=0.44$, see Table 1) (Pierrehumbert and Wyman 1985). The Rossby number Ro also increases to 2.12, revealing persistent transience after the upstream flow initially impinges on the ridge. The transient upstream flow blocked by the ridge finally veers to the west with the föhn breakdown (Fig. 5). Above the inversion and the blocking area, Fig. 5 displays a stronger south-westerly flow between 2000 and $3500 \mathrm{~m}$, veering westerly aloft with altitude. The cold-air stagnation blocked by the mountain range on the windward side is essential as it explains part of the strong cross-Alpine pressure gradient that gives birth to the föhn (Hoinka 1985).

Figure 11 shows a descending air mass in the lee: the air reaching the ground at the northern edge of the Alps originates from a level of $2000 \mathrm{~m}$ to $3500 \mathrm{~m}$ in the south (see isentropes in Fig. 11(a)). The air mass accelerates as it flows over the ridge and the Rhine Valley and experiences $15 \mathrm{~km}$ wavelength mountain waves (Fig. 12) penetrating down to the Rhine Valley (Fig. 13) and associated strong downward motion (Fig. 11). The differences between Meso-NH simulations and the observations along the trajectory of the CVB launched from Ispra, Italy on 30 October 1999 at 0811 UTC (Fig. 12) are less than $2 \mathrm{~m} \mathrm{~s}^{-1}$ for the horizontal wind speed, $10^{\circ}$ for the wind direction, $1.2 \mathrm{~K}$ for the 
(a)

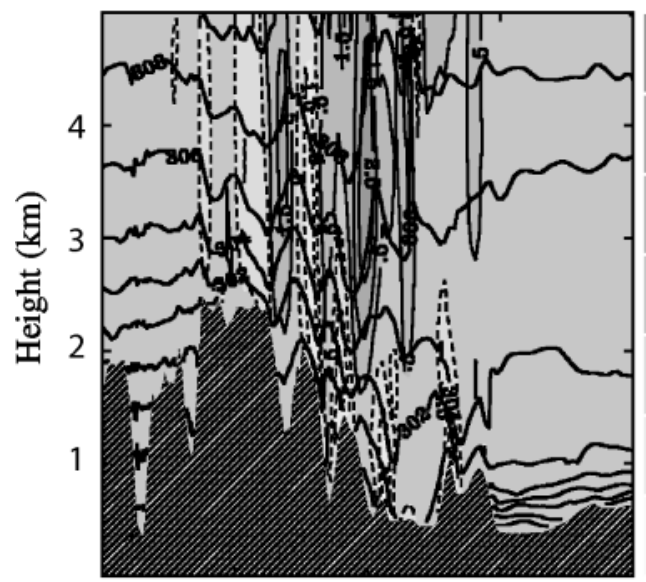

46.
47.

Latitude $\left({ }^{\circ}\right)$ (b)

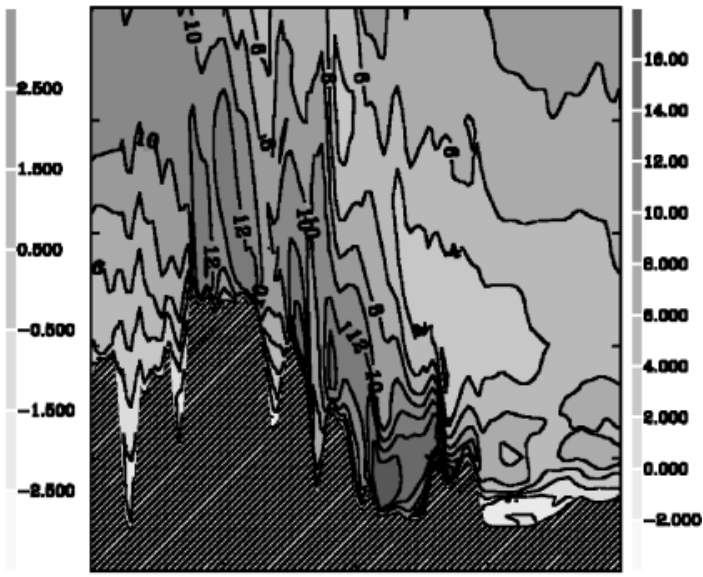

47.

48.

Latitude $\left({ }^{\circ}\right)$

Figure 11. Vertical cross-section of Meso-NH (a) vertical velocity (grey scale, $\mathrm{m} \mathrm{s}^{-1}$ ) and potential temperature (isentropes in solid line, K), and (b) south-north wind component (grey scale, m s${ }^{-1}$ ) on 30 October 1999 at 1200 UTC between $\left(9.5^{\circ} \mathrm{E}, 46.0^{\circ} \mathrm{N}\right)$ and $\left(9.5^{\circ} \mathrm{E}, 48.0^{\circ} \mathrm{N}\right)$. This cross-section transects the centre of RV2 (see text).
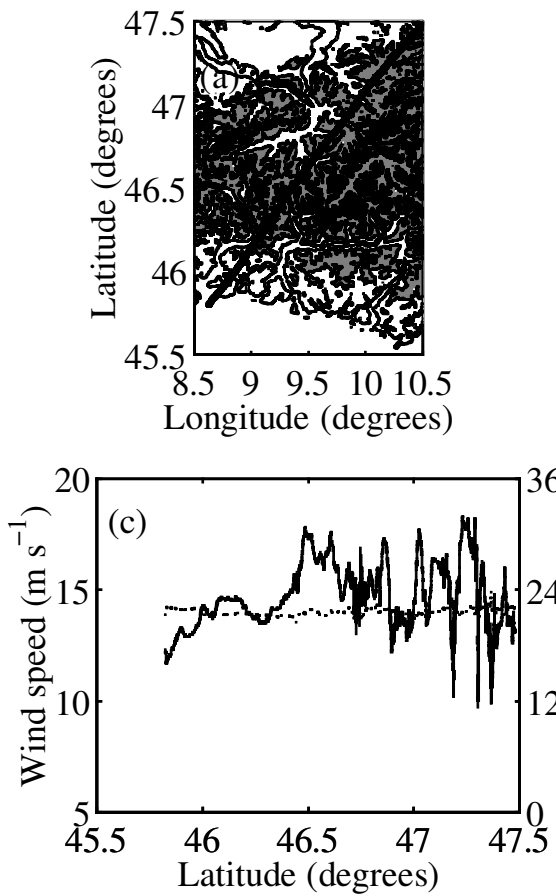
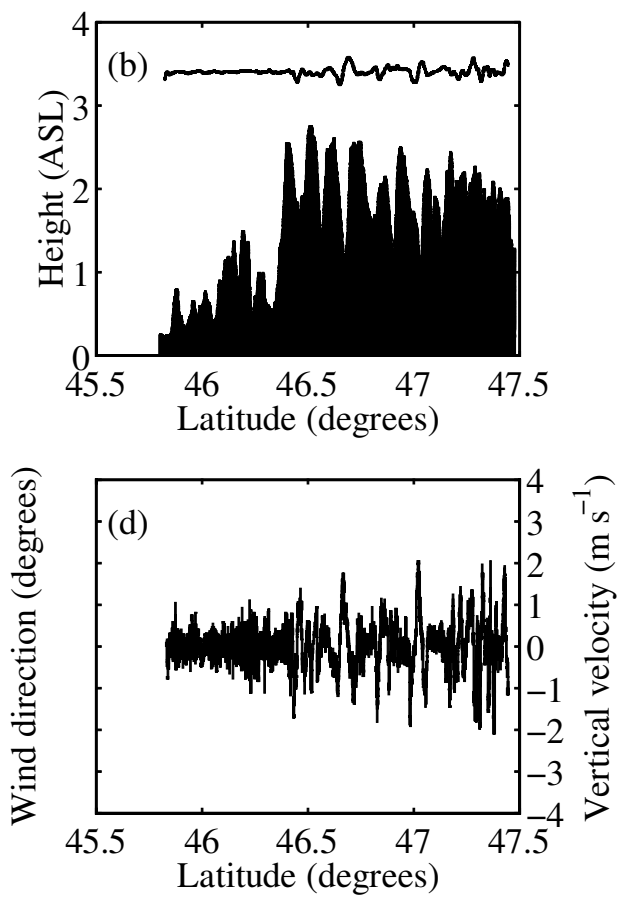

Figure 12. Measurements collected by the constant-volume balloon (CVB) launched from Ispra, Italy on 30 October 1999 at about 0800 UTC. (a) CVB trajectory; (b) flight altitude; (c) wind speed (solid line) and direction (dotted line); (d) vertical velocity. The flight lasted about 5 hours. 

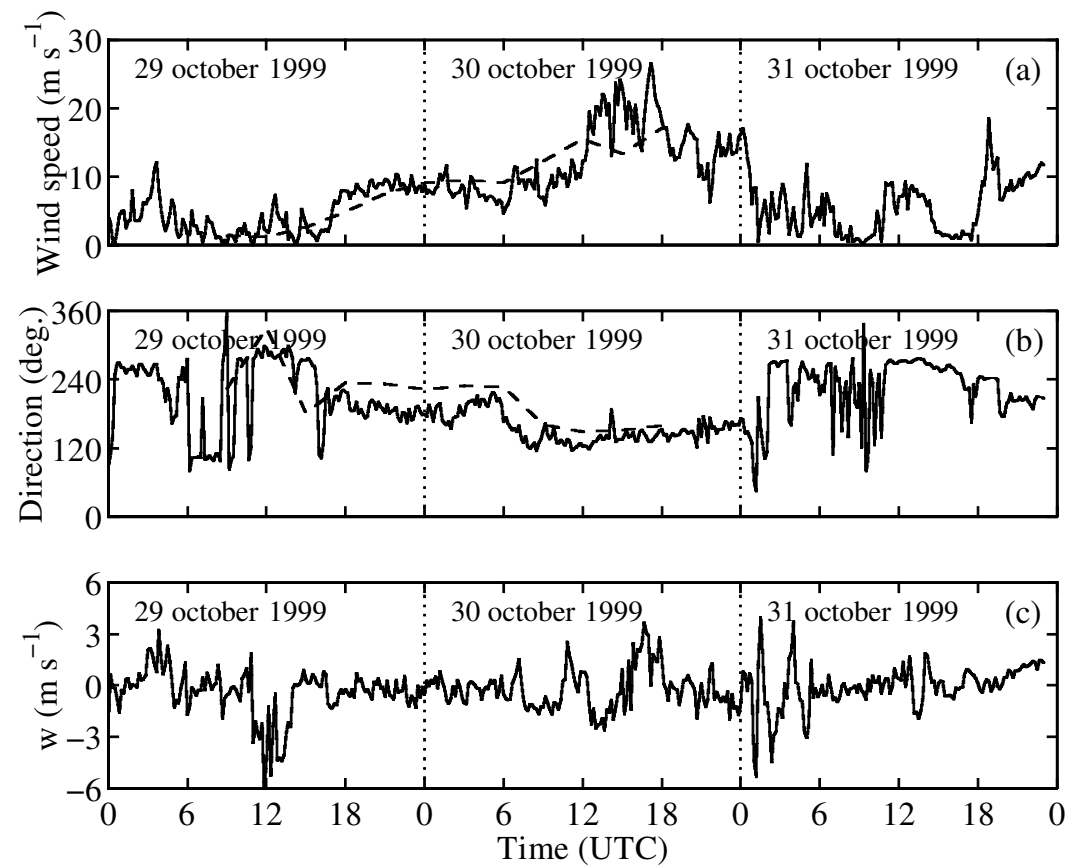

Figure 13. (a) Horizontal wind velocity, (b) direction and (c) vertical velocity, retrieved from the scintillometers (solid line) and from Meso-NH numerical simulations (dashed line).

potential temperature and $0.25 \mathrm{~g} \mathrm{~kg}^{-1}$ for the mixing ratio. The CVB observations show an increase of the wind speed near the mountain ridge, a constant flow direction, no large variation of the temperature $(305.2 \mathrm{~K} \pm 1.2 \mathrm{~K})$ or humidity $\left(3.0 \mathrm{~g} \mathrm{~kg}^{-1} \pm 0.3 \mathrm{~g} \mathrm{~kg}^{-1}\right)$ (as observed during IOP 2 and 8, for instance) and vertical oscillations when the CVB reaches the mountain ridge. The isentropes are almost horizontal on the southern side of the Alps, with a drop of up to $3 \mathrm{~km}$ on the lee side. The induced downslope winds on the northern side (e.g. Smith 1985) generate turbulence in the Rhine Valley as strong turbulent kinetic energy is simulated (not shown).

A rough estimate of the downslope surface wind can be computed by applying the steady-state equation of motion, i.e. when the pressure gradient term balances the advection term (e.g. Hoinka 1985; Hoinka and Rösler 1987). Using the observed pressure gradient of $8.5 \mathrm{hPa}$ across the Alps (see section 4 ), we get a downslope wind velocity of $19 \mathrm{~m} \mathrm{~s}^{-1}$ which is in good agreement with the observations and simulations (e.g. Fig. 13). In the middle troposphere, wide spacing between the isentropes indicates destabilization and strong mixing with eventual wave overturning.

As the upstream upper-level flow is quasi-aligned with the longitudinal valleys, the channelling efficiency of these valleys in directing the föhn flow towards the FORM target area increases. Val Lumnezia plays a significantly more important role than during the shallow föhn, whereas the Praettigau does not channel the föhn flow (not shown). The intensification of the föhn flow is visible in Fig. 10(m) at $1000 \mathrm{~m} \mathrm{ASL}$ where the flow splits at the bifurcation of the Rhine and Seez Valleys. At higher levels (Figs. 10(n) and (o)), the radial-velocity field is very weak in SV, due to a strong downslope transverse wind from the Weisstannen Valley (note the blue area at the exit of the Weisstannen Valley meaning that the flow blows towards the TWL in Fig. 10(n)) and due to downward motion induced by the coupling between lower- and upper-level flows 
and mountain waves. The vertical velocity measured by the scintillometers provides evidence of a strong interaction between the low-level föhn jet and wave activity aloft in the free troposphere (Fig. 13). The magnitude of the downward motion can reach $3 \mathrm{~m} \mathrm{~s}^{-1}$, so air masses advected from the south-west penetrate the Rhine and Seez Valleys and, thus, squeeze the flow layer that splits between the Rhine and Seez Valleys.

Table 1 shows that similarly to the previous day, the major geophysical characteristics of the three longitudinal tributaries on 30 October 1999, favour geostrophic adjustment and nonlinear processes, at least in the Reuss Valley and the Domleschg. The dimensionless depth $\widetilde{\Delta H}=0.82$ of Val Lumnezia tends to a quasi-linear value, i.e. where linear theory provides meaningful predictions. Of course, a limitation of the scale analyses shown in Table 1 is the exclusion of: (1) strong local cross-valley flows on the kilometre scale due to valleys or gaps which drain the main valleys; (2) downslope acceleration due to thermal winds (e.g. breezes); or (3) slope-induced gravitational acceleration which can have a non-negligible impact.

\section{DeVElopment of THE FÖHN FLOW IN THE RHINE VALlEy AND ITS NEARBY TRIBUTARIES}

The IOP 12 föhn episode starts on 30 October 1999 at 0900 UTC and ends on 31 October 1999 at 0310 UTC. The detection of föhn and the determination of the start and end times of the episodes are given by the multi-parameter algorithm of Gutermann (1970) applied to the numerous surface measurements acquired in the Rhine Valley and its main tributaries. The algorithm is based on a thresholding of mean and gust valley winds, temperature increase $>3 \mathrm{~K}$ and low humidities during the whole period. The föhn episodes were determined for each station individually. A föhn event is defined by the earliest onset and by the latest end at any of the considered stations on the valley floor.

In this section, we analyse the different phases of the life cycle of this south föhn event. We focus particularly on the three-dimensional structure of the föhn flow as a function of time and:

- the time of occurence and cessation of flow splitting in the Rhine and Seez Valleys and its vertical extent,

- the spatial inhomogeneity of the föhn penetration within the Rhine Valley.

\section{(a) Phase I: Pre-event situation}

The wind field at surface level was very heterogeneous during the afternoon of 29 October 1999. The wind speed in the three valleys was at most $5 \mathrm{~m} \mathrm{~s}^{-1}$. The weak heating by the sun in late fall and the cloud cover (all stations in the target area reported more than 4 octas of high and middle clouds) prevented the development of thermally driven wind systems.

Figure 6 displays flow reversal in the Heiligkreuz sounding at 1200 UTC, with higher wind speeds at 1500 UTC. This layer is about $1000 \mathrm{~m}$ deep. Above Buchs-Grabs, the layer with very weak northerly winds has about the same depth. Above $2500 \mathrm{~m}$ we observe a strong westerly component (see also Fig. 10(d)).

The shallow flow reversal at about $1000 \mathrm{~m}$ ASL can be observed with more detail in SV from the TWL data (Fig. 10(a)) and in RV2 from the scintillometer measurements of horizontal wind speed and direction (Fig. 13). Figure 13 shows a weak westerly/northwesterly valley wind between 1200 UTC and 1700 UTC. A very good agreement is found between the Meso-NH numerical simulations (dashed lines in Fig. 13) and the 
scintillometer measurements, during this phase as well as during the other phases of the föhn life cycle.

\section{(b) Phase II: Sandwich shallow föhn}

Katabatic drainage flow in the Rhine Valley and its tributaries was established during the night from 29 October to 30 October 1999. The evolution of temperature, humidity and wind at surface stations in RV2 (see Fig. 4 for the Vaduz example) during the course of this night is very similar to that during one of the clear nights with very weak pressure gradients in late summer at the beginning of the SOP. In contrast to these clear nights, the contribution of radiative cooling to the katabatic flow on the night of 29/30 October 1999 is only small since large parts of the target area were covered by clouds. The only exception was the area between Malans and Heiligkreuz, where the cloud cover reduced to 4 octas during a few hours. The flow out of the Rhine Valley and its tributaries was supported by the isallobaric field. Whereas pressure decreased north of the Alps due to the low-pressure system approaching from the west (Fig. 2), it remained more or less constant south of the Alps. The second effect of this differential pressure change was the establishement of a weak flow across the gaps in the Alpine ridge into the valleys north of the Alps. Wind speeds at the Alpine ridge varied between 5 and $7 \mathrm{~m} \mathrm{~s}^{-1}$ at Guetsch, and 1 and $5 \mathrm{~m} \mathrm{~s}^{-1}$ at Piz Martegnas, whereas in the Rhine Valley at $1000 \mathrm{~m}$ ASL the wind speed was between 9 and $10 \mathrm{~m} \mathrm{~s}^{-1}$ (Fig. 13). This flow supported the katabatic flow but it was too weak and too shallow to replace the air flowing out of the Rhine and Seez Valleys and to become a real (shallow) föhn flow. The air flowing out of the Rhine and Seez Valleys was instead replaced by subsidence from above the large catchment of the Rhine Valley. The subsidence is confirmed by the temperature inversion which is higher in the southern part of the target area than in the northern parts (Fig. 6).

The katabatic flow reached Vaduz in RV2 and further than Quinten in SV. The wind speed at Vaduz was 3 to $4 \mathrm{~m} \mathrm{~s}^{-1}$ throughout this phase (Fig. 4). This is a typical value for thermally induced mountain wind (Egger 1990a, b). The humidity in the katabatic flow decreased from $70 \%$ on 29 October 1999 at 1900 UTC to $55 \%$ at the end of phase II at 0330 UTC on 30 October 1999.

North of Vaduz, the RV2 was covered by a shallow cold air pool. The thickness of this pool grew from less than $40 \mathrm{~m}$ at 1800 UTC on 29 October 1999 to $60 \mathrm{~m}$ at 2100 UTC and $0000 \mathrm{UTC}$, to $100 \mathrm{~m}$ at $0300 \mathrm{UTC}$, and $300 \mathrm{~m}$ at $0600 \mathrm{UTC}$ on 30 October 1999. The temperature in this cold air was 5-6 K lower than in the katabatic flow (Figs. 14 and 15, the Altenrhein station being in the cold air pool). Humidity in the cold air pool was near to saturation.

Due to the higher wind speed caused by channelling in the much narrower SV no distinct cold air pool developed in this valley (Figs. 14 and 15) (the simulated potentialtemperature field, not shown in the paper confirms this point). The channelling of the katabatic flow is clearly visible in the wind profile (Fig. 6). The maximum wind speed gradually came down from $1500 \mathrm{~m}$ ASL to $800 \mathrm{~m}$ ASL which is a further indication of the subsidence. At the surface, wind speeds remained low throughout the night and the temperature at Heiligkreuz fluctuated between $13{ }^{\circ} \mathrm{C}$ and $15^{\circ} \mathrm{C}$ (Fig. 15).

Between the valley flow described above and the large-scale synoptic southwesterly flow a shallow layer with southerly flow established during this phase. This layer was more pronounced in the south and central part of RV2 than in any other part of the target area. Above Buchs-Grabs it stretched from 1000 to $1800 \mathrm{~m}$ ASL at 1800 UTC on 29 October 1999, was squeezed to 900-1500 m ASL with increasing wind speed $\left(10 \mathrm{~m} \mathrm{~s}^{-1}\right.$ at $\left.1200 \mathrm{~m}\right)$ at $2100 \mathrm{UTC}, 0000 \mathrm{UTC}$ and $0300 \mathrm{UTC}$, and weakened again but 


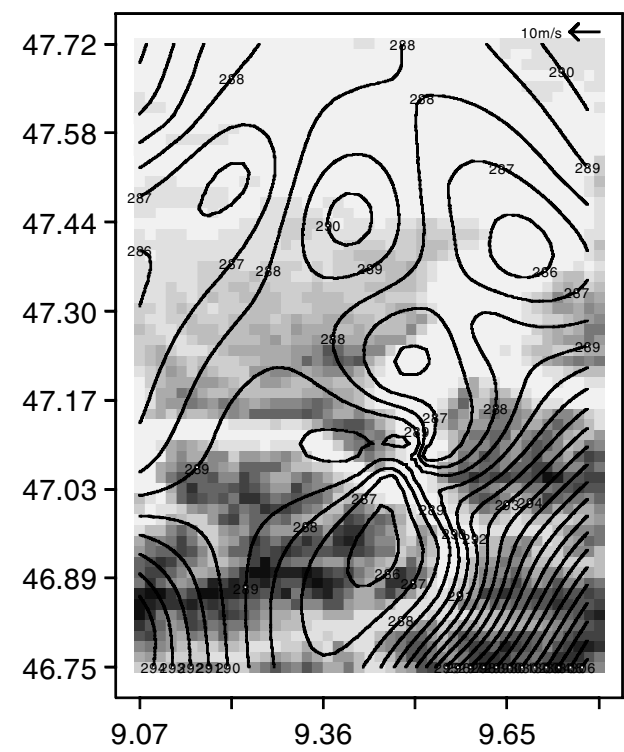

(a)

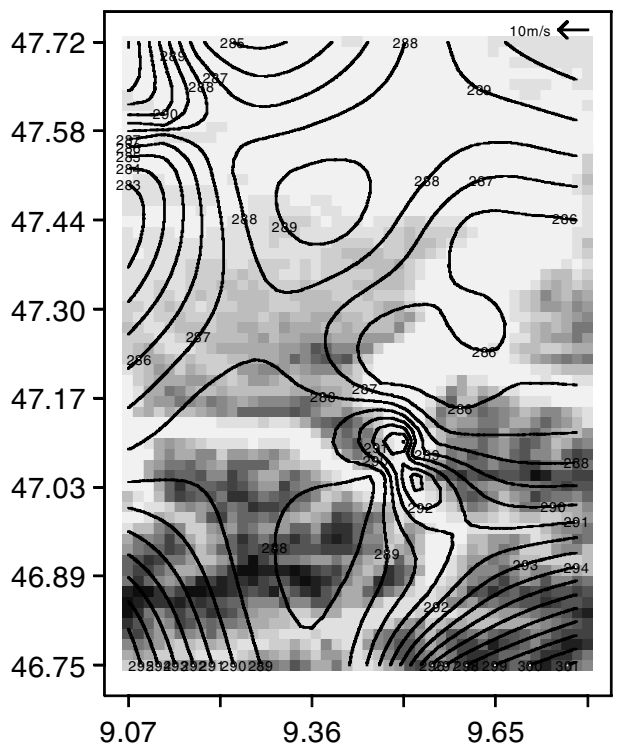

(b)

Figure 14. Surface potential-temperature analyses in the FORM (see text) target area during phase II using the VERA algorithm (see text). The analyses are shown (a) for 29 October 1999 at 1800 UTC and (b) for 30 October 1999 at 0300 UTC (the thermodynamical pattern does not evolve in between). The ordinates correspond to the longitude and the abscissae to the latitude.
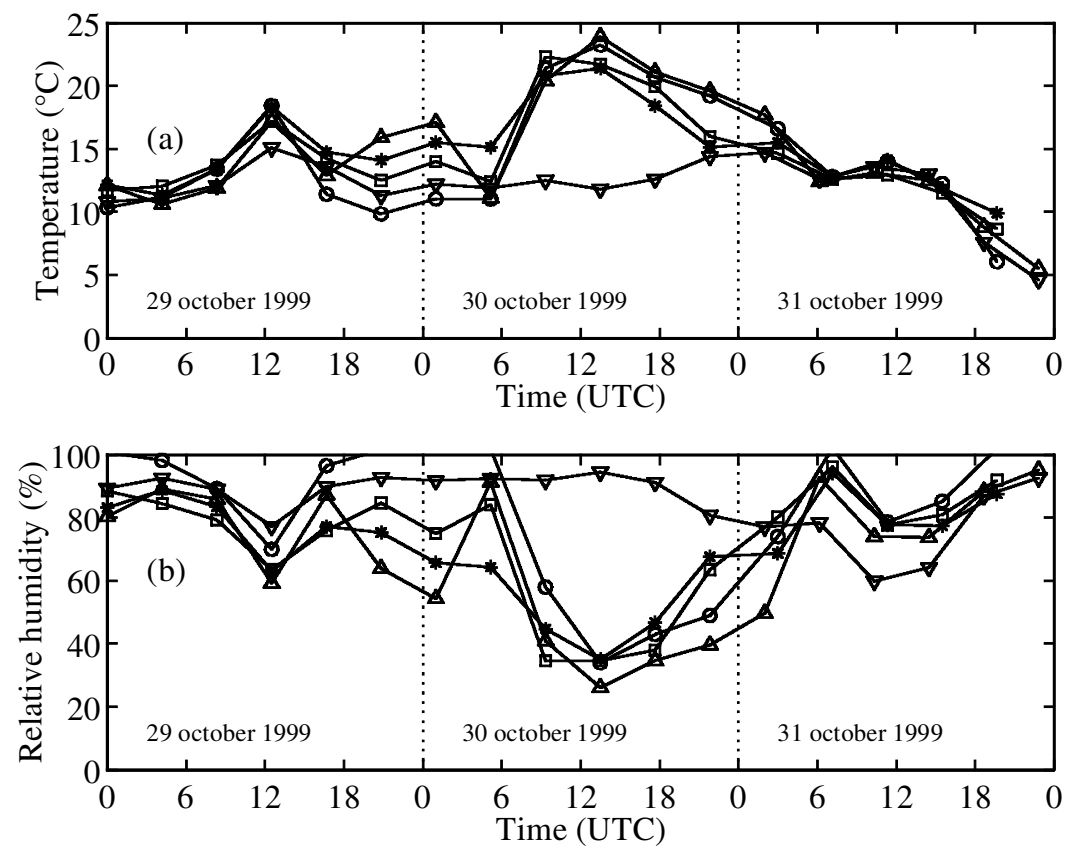

Figure 15. Time series of (a) surface temperature and (b) relative humidity, measured at Heiligkreuz ( $\square$ ), BuchsGrabs (०), Malans $(*)$, Vaduz $(\triangle)$ and Altenrhein $(\nabla)$. 


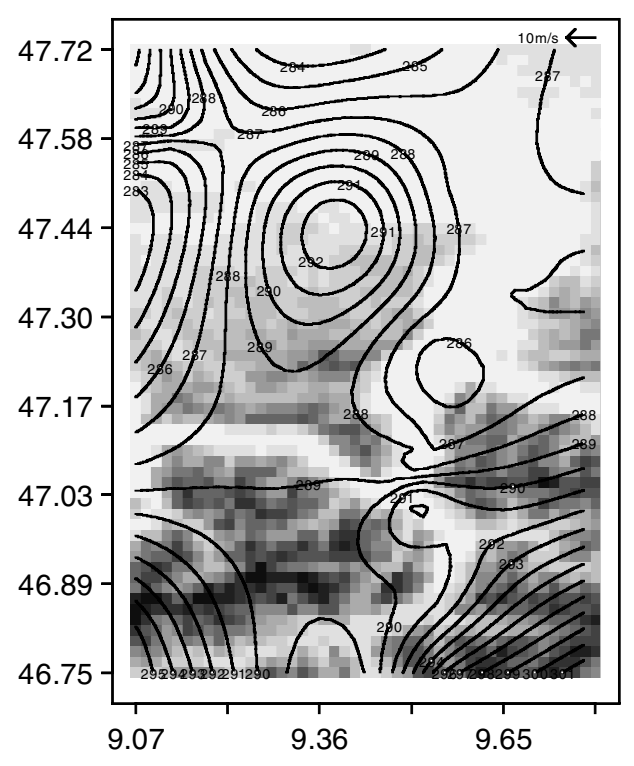

Figure 16. Same as Fig. 14 for phase III on 30 October 1999 at 0600 UTC.

stretched from 800 to $3100 \mathrm{~m}$ at 0600 UTC on 30 October 1999 (Fig. 6). This layer was continuously recorded by the scintillometers (Fig. 13). The changes in depth and speed coincide well with the higher wind speeds at the pass stations between 2100 UTC and 0300 UTC. Also, since the potential temperature in this flow is the same as at the passes (Guetsch at $2287 \mathrm{~m} \mathrm{ASL}$ ) we can firmly assume that this flow is that part of the flow which crosses the gaps in the Alpine divide. Because this shallow föhn flow does not reach the valley floor (as it should in order to fulfill the conventional definitions) and it is caught between the katabatic flow below and the large-scale synoptic flow above, the term 'sandwich shallow föhn' is appropriate to describe the flow.

\section{(c) Phase III: Cold air pool covers RV2}

The regime described in the previous section lasted until 0400 UTC on 30 October 1999. During phase II, the mesoscale pressure minimum was situated in the northern part of RV2 or even north of it. Between noon on 29 October 1999 and midnight, pressure decreased by $1-2 \mathrm{hPa}$ in the south of the target area, but by $4 \mathrm{hPa}$ in its northern parts. Starting at 0300 UTC, the pressure field established during phase II was disturbed. A small zone of higher pressure was established in the very northern parts of the Rhine Valley. Due to the steadily falling pressure, the pressure minimum in RV2 moved to the area between Vaduz and Sargans, in the southern parts of RV2. This caused a flow reversal in the upper parts of RV2, and allowed the cold air pool to pour into the region where we had katabatic flow during phase II (see Fig. 16 and Fig. 4 for the Vaduz example). The wind in this area turned to a northerly direction. The moisture content in the cold air pool was near to saturation (Fig. 15), but Diepoldsau was the only station which reported fog at 0700 UTC on 30 October 1999. Phase III lasted until 0700 UTC when the temperature started to increase rapidly. At most stations in the southern part of RV2 the same katabatic flow as in phase II established for a short time and later the temperature further increased. 


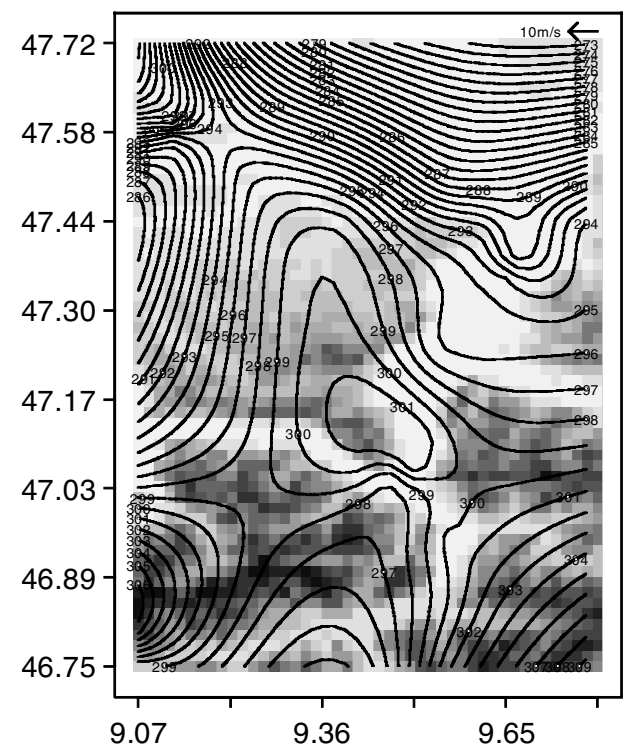

(a)

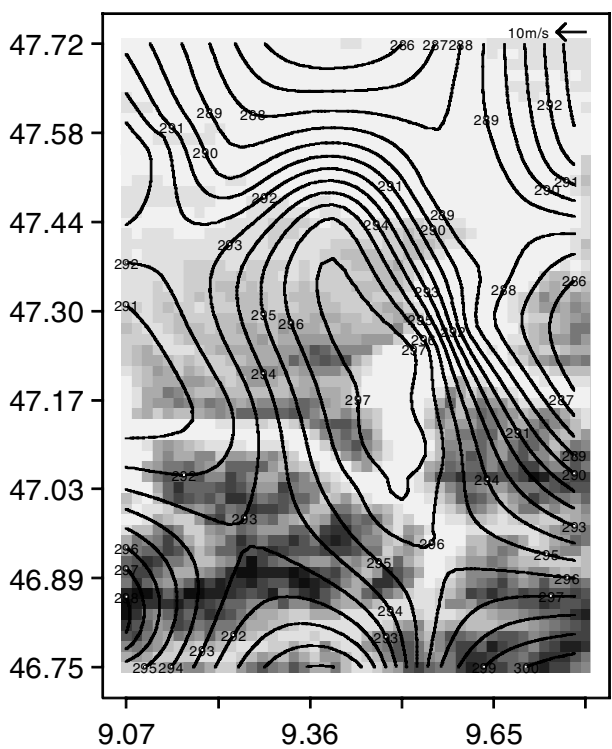

(c)

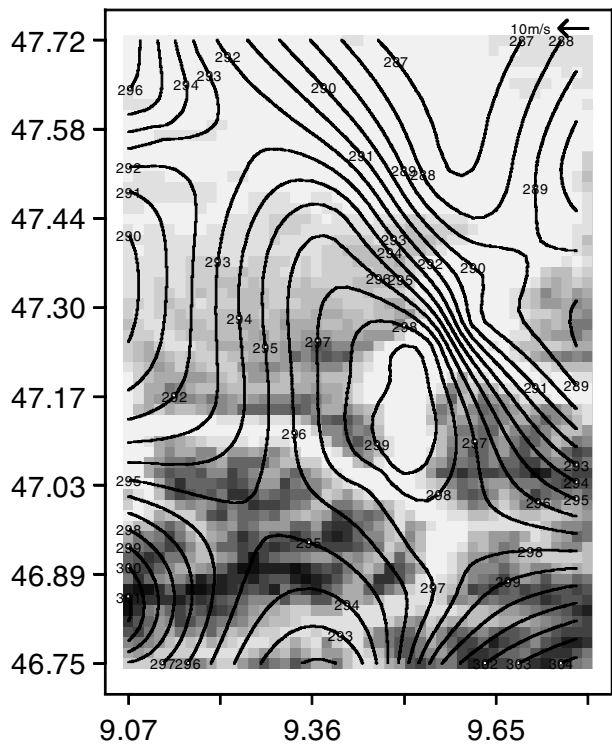

(b)

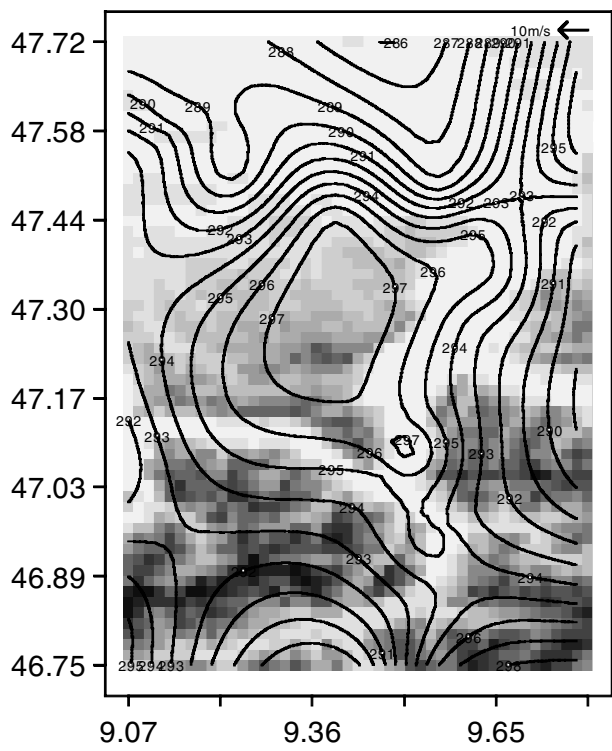

(d)

Figure 17. Same as Fig. 14 for phase IV on 30 October 1999 at (a) 1200 UTC, (b) 1500 UTC, (c) 1800 UTC and (d) 2100 UTC.

(d) Phase IV: Penetrating föhn in RV1, RV2 and SV

The main reason for the intensification of the föhn flow in RV and SV was the increasing cross-Alpine pressure difference which grew from $6 \mathrm{hPa}$ at $0600 \mathrm{UTC}$ to $8.5 \mathrm{hPa}$ at 1200 UTC on 30 October 1999 (Fig. 3), and the rotation of the upperlevel flow from west to south-west (Fig. 10(p), fourth row). The change in the flow regime around 0600 UTC is clearly visible in Fig. 13 when the wind direction at about 
$1000 \mathrm{~m}$ ASL changed from $180^{\circ}$ to $140^{\circ}$. This jump in wind direction, as well as the intensification of the flow, is visible in the Meso-NH simulation outputs. It becomes clear from the scintillometer wind speed, that the gusty and strong föhn flow started only at noon (Fig. 13). Thus, the main effect, until about 1200 UTC, of the föhn flow was the enhancement of the diurnal cycle, i.e. the temperature increase during the morning hours was steeper than the previous day. The first temperature maximum was reached about 1 hour earlier and was $1-2 \mathrm{~K}$ higher than during the previous day (Fig. 15). The cold air pool had almost completely disappeared by 0900 UTC in RV1 and by 1200 UTC in SV and RV2 (Fig. 17(a)). Almost all stations between Masein in the southern tributary of RV1, and Ruggel in RV2, and Heiligkreuz in SV, show a clear positive jump in temperature and a negative jump in humidity between 1100 UTC and 1400 UTC on 30 October 1999 (Fig. 6). This is a clear indication that the föhn flow touched the surface. The distribution of potential temperature shows a well established föhn flow at 1500 UTC (Fig. 17(b)) which propagates at about $4.5 \mathrm{~km} \mathrm{~h}^{-1}$. This led to a short-term small-scale pressure fall in the basin of Buchs-Grabs. The pressure minimum in RV2 was situated in this area for about 2 hours. As a consequence, the cold air pool situated in the northern parts of RV2 oscillated back to the south into the basin of Buchs-Grabs, and the temperature gradient between the föhn air and the cold air pool increased. At 1800 UTC, the border between the föhn flow and the cold air pool was again further to the north (Fig. 17(c)) and at 1900 UTC the föhn touched the surface at Diepoldsau (Fig. 17(d)). During the following hour, the föhn flow at the surface was confined to the western valley wall due to the katabatic flow coming from the Walgau, east of Feldkirch. It was not until 2200 UTC that the föhn also touched the surface at Feldkirch. The cold air flow out of the Walgau was stronger and cut the föhn flow into a southern patch (from Balzers to Buchs-Grabs) and a northern part (Diepoldsau-Götzis) before the föhn was completely stopped by the approaching cold front at 0200 UTC.

\section{CONCLUSION}

This paper examines the three-dimensional structure and dynamics of the IOP 12 south föhn flow during its entire life cycle from 29 October 1999 until 31 October 1999 in the Rhine Valley, and specifically in the FORM target area at the bifurcation between the Rhine and Seez Valleys, near Bad Ragaz, Switzerland. This south föhn case presents several levels of complexity:

- In the time domain, this föhn life cycle has strong similarities to Seibert's (1990) description, but also reveals the higher complexity of the föhn flow in the Rhine Valley compared with the comparatively simple structure in the Wipp Valley, on which Seibert's föhn life cycle is mainly based. As would be expected for a large valley with an extensive catchment, katabatic flow and cold air pools play an important role by preventing the föhn flow touching the ground. In addition, the topographical configuration in the Wipptal-Innsbruck area enable the quite simple distinction between katabatic flow and (shallow) föhn, because there is a change in the wind direction of roughly 90 degrees. In the Rhine Valley, katabatic flow and shallow föhn have very similar, at some places even identical, wind direction, which makes the distinction very difficult (Drobinski et al. 2003).

- In the space domain, strong interactions are shown between the synoptic scales that force cross-Alpine temperature, humidity and pressure gradients, the mesoscales that drive the föhn circulation in the complex valley network, and the local scales that cause highly inhomogeneous thermodynamical patterns. 
In the FORM target area, the thermodynamical pattern is extremely inhomogeneous (both horizontally and vertically) and varies with time. This paper investigates in detail the multiscale processes driving interactively the structure of the cold air pool and the warm föhn air. These are:

- Local forcing: radiative cooling, local pressure and temperature gradients (cold pool, thermal winds, ... ).

- Mesoscale forcing by the valleys: complex valley network tributaries directing the flow towards the FORM target area, flow splitting at bifurcations between valleys, föhn flow splitting near Feldkirch by cold air flowing out the Walgau, ... .

- $\quad$ Synoptic-scale forcing, such as large-scale pressure gradients driving the direction and intensity of the katabatic and föhn flows in the valley, and coupling between the valley flow and tropospheric mountain waves.

Future work will focus on the processes of interaction between the tropospheric waves and the föhn flow, or more generally the planetary boundary layer. Also, in the framework of MAP, the Wipp Valley was highly instrumented, and thorough comparisons can be made between the föhn structure, intensity and evolution in the Rhine and Wipp Valleys.

\section{ACKNOWLEDGEMENTS}

The authors would like to thank the scientists of the MAP FORM working group, coordinated by H. Richner, and particularly G. Jaubert and G. Beffrey for fruitful discussions; B. Bénech and $\mathrm{H}$. Berger for providing the constant-volume balloon data and help in analysing them; M. Aupierre, C. Boitel, A. Delaval, P. Delville, J. M. Donier, C. Loth and B. Romand for assistance in operating the TWL during the MAP field experiment; M. C. Lanceau for help in collecting the referenced papers; E. Haeller for the MAP data centre management. The effort in collecting radiosonde measurements in a dense network and at high temporal resolution by the Swiss Army joint Meteorological Services is gratefully acknowledged. These stations were significantly supported with data loggers and computer hardware by Meteolabor AG and Polyinformatik GmbH. This research was funded by the Centre National de Recherche Scientifique (CNRS) through the Programme ATmosphère Océan à Méso-échelle (PATOM), the Institut National des Sciences de l'Univers (INSU) and by the Centre National d'Études Spatiales (CNES).

Bechtold, P., Bazile, E.,

Guichard, F., Mascart, P. and

Richard, E.

Bougeault, P. and Lacarrère, P.

Bougeault, P., Binder, P., Buzzi, A., Dirks, R., Houze, R.,

Kuettner, J., Smith, R. B.,

Steinacker, R. and Volkert, H. Brinkmann, W. A. R.

Dabas, A. M., Drobinski, P. and Flamant, P. H.

Drobinski, P., Dabas, A. M., Haeberli, C. and Flamant, P. H.

\section{REFERENCES}

2001 A mass flux convection scheme for regional and global models. Q. J. R. Meteorol. Soc., 127, 869-886

1989 Parametrization of orography-induced turbulence in a meso-beta scale model. Mon. Weather Rev., 117, 1872-1890

2001 The MAP special observing period. Bull. Am. Meteorol. Soc., 82, 433-462

1971 What is Foehn? Weather, 26, 230-239

1974 Strong downslope winds at Boulder, Colorado. Mon. Weather Rev., 102, 592-602

1999 Adaptive filters for frequency estimates of heterodyne Doppler lidar returns: Recursive implementation and quality control. J. Atmos. Oceanic Technol., 16, 361-372

2001a On the small-scale dynamics of flow splitting in the Rhine valley during a shallow foehn event. Boundary-Layer Meteorol., 99, 277-296 
Drobinski, P., Dusek, J. and Flamant, C.

Drobinski, P., Flamant, C., Dusek, J., Flamant, P. H. and Pelon, J.

Drobinski, P., Dabas, A. M., Haeberli, C. and Flamant, P. H. Egger, J.

Flamant, C., Drobinski, P.,

Nance, L., Banta, R. M.,

Darby, L., Dusek, J.,

Hardesty, R. M., Pelon, J. and Richard, E.

Furger, M., Drobinski, P., Prévôt, A. S. H., Weber, R. O., Graber, W. K. and

Neininger, B.

Gutermann, T.

Heimann, D.

Hoinka, K. P.

Hoinka, K. P. and Rösler, F.

Koffi, E. N., Georgelin, M., Benech, B. and Richard, E.

Lafore, J. P., Stein, J., Asencio, N., Bougeault, P., Ducrocq, V., Duron, J., Fischer, C., Héreil, P., Mascart, P., Masson, V., Pinty, J. P., Redelsperger, J. L., Richard, E. and

Vilà-Guerau de Arellano, J.

Morcrette, J.-J.

Nkemdirim, L. C. and Leggat, K.

Noilhan, J. and Planton, S.

Overland, J. E.

Pierrehumbert, R. T. and Wyman, B.

Poggio, L., Furger, M., Prévôt, A. S. H., Graber, W. K. and Andreas, E. L.

Seibert, $\mathrm{P}$.

Smith, R. B.

Sprenger, M. and Schär, C.

Stein, J., Richard, E., Lafore, J. P., Pinty, J. P., Asencio, N. and Cosma, S.

2003

1988

$1990 \mathrm{a}$

$1990 \mathrm{~b}$

2002

1992

2000

1998

1991

2000

1990

1985

2001

2000
Diagnostics of hydraulic jump and gap flow in stratified flows over topography. Boundary-Layer Meteorol. , 98, 475-495

2001c Observational evidence and modelling of an internal hydraulic jump at the atmospheric boundary-layer top during a Tramontane event. Boundary-Layer Meteorol., 98, 497-515

Radiation and cloud radiative properties in the European Centre for Medium-Range Weather Forecasts forecasting system. J. Geophys. Res., 96, 9121-9132

The effect of chinook weather on urban heat islands and air pollution. Water, Air and Soil Pollution, 9, 53-67

A simple parameterization of land surface processes for meteorological models. Mon. Weather Rev., 117, 536-549

1984 Scale analysis of marine winds in straits and along mountainous coasts. Mon. Weather Rev., 112, 2530-2534

1985 Upstream effects of mesoscale mountains. J. Atmos. Sci., 42, 9771003

Scintillometer wind measurements over complex terrain. J. Atmos. Oceanic Technol., 17, 17-26

South foehn studies since the ALPEX experiment. Meteorol. Atmos. Phys., 43, 91-103

On severe downslope winds. J. Atmos. Sci., 42, 2597-2603

Rotational aspects of stratified gap flows and shallow föhn. Q. J. R. Meteorol. Soc., 127, 161-188

High-resolution non-hydrostatic simulations of flash-flood episodes with grid-nesting and ice phase parameterization. Meteorol. Atmos. Phys., 72, 203-221 
Steinacker, R., Haeberli, C. and Pöttschacher, W.

Steinacker, R., Haeberli, C.,

Baumann, K., Gubser, S.

Lothon, M. and Gutermann, T.

Vergeiner, J. and Mayr, G.

Wippermann, F.

Zängl, G.
2000 A transparent method for the analysis and evaluation of irregularly distributed and noisy observational data. Mon. Weather Rev., 128, 2303-2316

2003 Unstationary aspects of foehn in a large valley: Scientific objectives and description of the foehn cases during the MAP subprogram FORM. Meteorol. Atmos. Phys., in press

2000 'Case study of the MAP-IOP 'sandwich' foehn on 18th October 1999'. In proceedings of the 26th international conference on Alpine meteorology, 11-15 September 2000, Innsbruck

1984 Air flow over and in broad valleys: Channelling and countercurrent. Beitr. Phys. Atmos., 57, 92-105

1999 Three-dimensional idealized simulations of the foehn in the region of Innsbruck. Contrib. Atmos. Phys., 72, 243-266

2002 Idealized numerical simulations of shallow föhn. $Q$. J. $R$. Meteorol. Soc., 128, 431-450 